\title{
In-Situ Kd Values nad Geochemical Behavior for Inorganic and Organic Constituents of Concern at the TNX Outfall Delta
}

by

D. I. Kaplan

Westinghouse Savannah River Company

Savannah River Site

Aiken, South Carolina 29808

S. M. Serkiz

RECEIVED

FFR 232000

OSTI

DOE Contract No. DE-AC09-96SR18500

This paper was prepared in connection with work done under the above contract number with the U.S.

Department of Energy. By acceptance of this paper, the publisher and/or recipient acknowledges the U.S.

Government's right to retain a nonexclusive, royalty-free license in and to any copyright covering this paper, along with the right to reproduce and to authorize others to reproduce all or part of the copyrighted paper. 


\section{DISCLAIMER}

This report was prepared as an account of work sponsored by an agency of the United States Government. Neither the United States Government nor any agency thereof, nor any of their employees, makes any warranty, express or implied, or assumes any legal liability or responsibility for the accuracy, completeness, or usefulness of any information, apparatus, product or process disclosed, or represents that its use would not infringe privately owned rights. Reference herein to any specific commercial product, process or service by trade name, trademark, manufacturer, or otherwise does not necessarily constitute or imply its endorsement, recommendation, or favoring by the United States Government or any agency thereof. The views and opinions of authors expressed herein do not necessarily state or reflect those of the United States Government or any agency thereof.

This report has been reproduced directly from the best available copy.

Available for sale to the public, in paper, from: U.S. Department of Commerce, National Technical Information Service, 5285 Port Royal Road, Springfield, VA 22161

phone: (800) 553-6847

fax: (703) 605-6900

email: orders@ntis.fedworld.gov

online ordering: http://www.ntis.gov/ordering.htm

Available electronically at http://www.doe.gov/bridge

Available for a processing fee to U.S. Department of Energy and its contractors, in paper, from: U.S. Department of Energy, Office of Scientific and Technical Information, P.O. Box 62, Oak Ridge, TN 37831-0062

phone: (865)576-8401

fax: (865)576-5728

email: reports@adonis.osti.gov 


\section{DISCLAIMER}

Portions of this document may be illegible in electronic image products. Images are produced from the best available original document. 
Keywords: Distribution coefficients, TNX, metals, radionuclides, sequential extractions, colloids

Retention: Permanent

\section{In-Situ Kd Values and Geochemical Behavior for Inorganic and Organic} Constituents of Concern at the TNX Outfall Delta (U)

January 21,2000

Daniel I. Kaplan

Steven M. Serkiz

Waste Processing Technology

Savannah River Technology Center

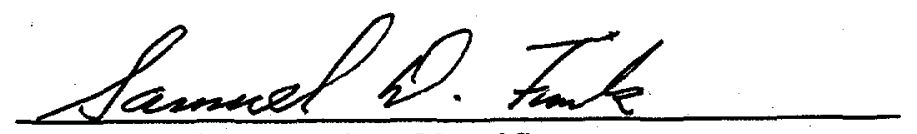

Authorized Derivative Classifier

Savannah River Technology Center

Westinghouse Savannah River Company

Aiken, SC 29808 
Keywords: Distribution coefficients, TNX, metals, radionuclides, sequential extractions, colloids

Retention: Permanent

\section{In-Situ Kd Values and Geochemical Behavior for Inorganic and Organic Constituents of Concern at the TNX Outfall Delta (U)}

January 21,2000

Daniel I. Kaplan

Steven M. Serkiz

Waste Processing Technology

Savannah River Technology Center

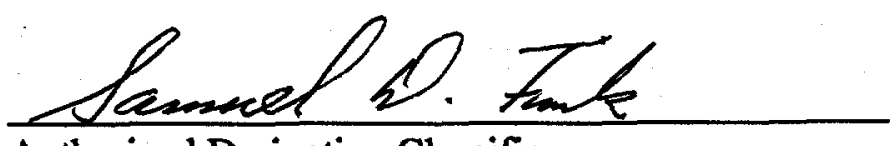

Authorized Derivative Classifier

Savannah River Technology Center

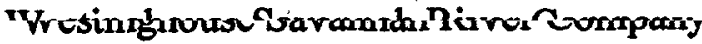

Aiken, SC 29808 


\section{Authors}

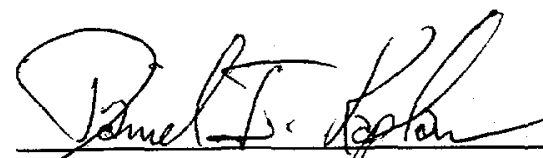

D. I. Kaplan, Wasted Disposal \& Environmental Development Group
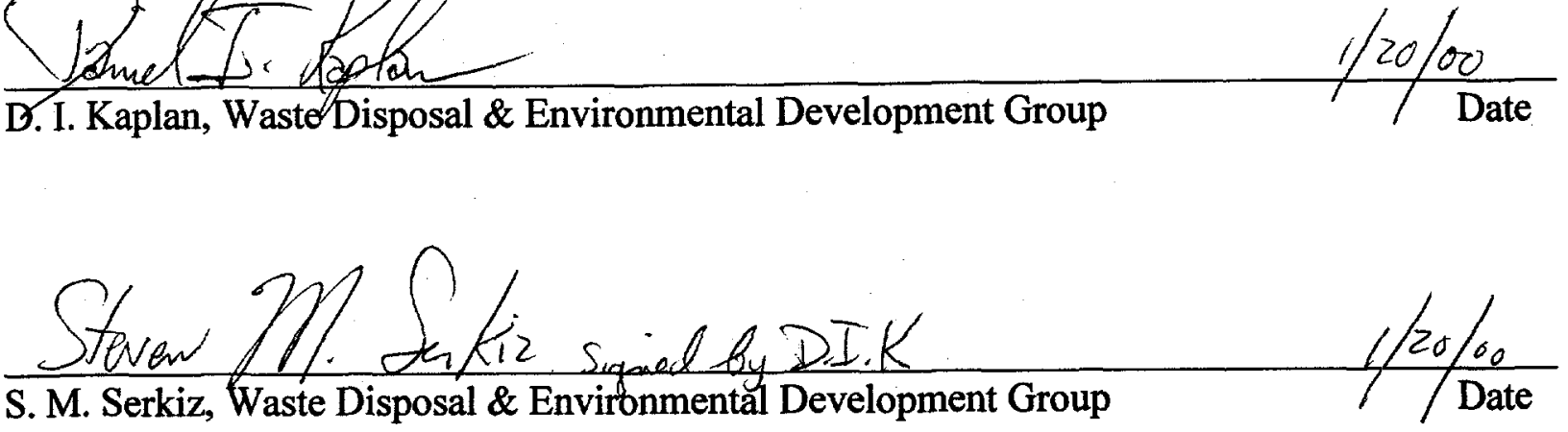

\section{Design Check}

\section{Approvals}

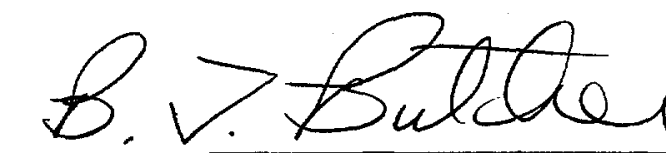

$$
1-20-00
$$

B. T. Butcher, Level 4 Manager Date

Waste Disposal \& Environmental Development Group 


\section{Executive Summary}

A series of tests were conducted to provide site-specific Kd values for constituents of concern (COCs) at the TNX Outfall Delta Operable Unit (TNXOD OU). These Kd values can be used to calculate contaminant migration within the operable unit and are, at this time considered to be the most defensible values. Additional sequential extraction tests were conducted to evaluate the "environmental availability" (i.e., the strength that the contaminants are associated with sediments) of COCs sorbed to the site's sediments. This concept was subsequently used to determine which sediment fractions were responsible for COC sorption. These latter tests provided important supporting data for technically defending the selected "Reasonably Conservative" Kd estimates.

$\mathrm{Kd}$ values were determined primarily by desorption measurements of contaminated sediments collected from the study site. For those COCs that were not present in the sediment samples, Kd values were determined either by sorption (which includes adsorption, absorption, and precipitation) tests or by using a common EPA-approved method based on literature-derived organic matter/water partition coefficients $\left(\mathrm{K}_{\mathrm{om}}\right)$. Based on its intended use, the desorption $\mathrm{Kd}$ test provides the best measure of contaminant association with the site's sediment because the desorption process typically controls solute transport more than the sorption process. Additionally, unlike the sorption tests, desorption tests capture the contaminant "aging" process within the sediment. Some of the COCs had been in contact with the sediments used in this study for greater than 30 years. The desorption Kd values were based on extractable portions that were comprised of the "exchangeable," "organic-bound," the "amorphous Fe-oxide bound," and the "saturated-paste, water extractable" fractions. These sediment fractions are more likely to sorb or desorb contaminants than the fraction of the $\mathrm{COC}$ inside the mineral or crystalline $\mathrm{Fe}$ oxide structure. By basing the Kd estimates on these extractable fractions, instead of the more easily determined total-concentrations in the sediment, more conservative and technically defensible Kd values were measured. "Reasonably Conservative" and "Upper Limit" Kd values were estimated based on sorption and desorption tests and were based on the lowest and highest measured values, respectively (see table below).

In general, most of the in-situ Kd values were appreciably larger than default conservative $\mathrm{Kd}$ values used in previous contaminant transport calculations. In the case of the desorption experiments, the cause for the large values can in part be attributed to the contaminants having several years to "age" with the sediments. During the aging process, the sorbed contaminants may be incorporated into the structure of the solid phase or be buried on the solid phase beneath recently formed precipitates, thereby limiting re-entry into the mobile aqueous phase. The organic-COC Kd values were generally quite low. This may be attributed to the implicit assumption associated with the calculation that sorption occurs only by partitioning to the organic matter and not to the mineral phase. This assumption is increasingly inaccurate as the hydrophobicity of organic solute and the mineral surface area increases.

The sequential extraction experiment revealed that $\mathrm{Cu}, \mathrm{Hg}$, and $\mathrm{Pb}$ were strongly bound onto the sediment, providing supporting evidence for selecting large $\mathrm{Kd}$ values for these COCs. 
Conversely, $\mathrm{Cd}, \mathrm{Cr}, \mathrm{Co}$, and $\mathrm{Tl}$, tended to be associated with the "exchangeable" and "organically bound" fractions, suggesting that lower Kd values be selected for these COCs. COC concentrations were measured in the whole sediment, the $<2-\mu \mathrm{m}$ fraction, and the $<0.5-\mu \mathrm{m}$ fractions. The motivation behind this work was the hypothesis that some of the less soluble COCs, such as $\mathrm{Th}$ and $\mathrm{Hg}$, may have been transported at the study site via association with mobile particles (including colloids). Among the most contaminated sediments, there was only sporadic evidence of contaminant-concentration enrichment in the smaller fractions. These data do not rule out the possibility that COCs may be moving via particulate transport, but do strongly suggest that particulates are not the only means for transporting the COCs.

The sequential extraction and the COC concentration versus size fraction data also have important implications for the selection of remediation strategies. Due to their greater environmental availability, $\mathrm{Cd}, \mathrm{Cr}, \mathrm{Co}, \mathrm{Tl}, \mathrm{Th}$, and $\mathrm{U}$ are more likely to be remediated by phytoremediation or solvent extraction than $\mathrm{Cu}, \mathrm{Pb}$, and $\mathrm{Hg}$. Conversely, $\mathrm{Cu}, \mathrm{Pb}$, and $\mathrm{Hg}$ would make better candidate contaminants for monitored natural attenuation than $\mathrm{Cd}, \mathrm{Cr}, \mathrm{Co}, \mathrm{Tl}, \mathrm{Th}$, and $\mathrm{U}$. The $\mathrm{COC}$ concentration versus size fraction data suggested that soil washing, which removes the smaller size fraction of contaminated sediments, would not be an effective strategy for remediating these sediments.

\begin{tabular}{|c|c|c|c|c|c|}
\hline \multicolumn{6}{|c|}{ Reasonably-Conservative and Upper Limit Kd Estimates Based on in-situ, Kd Measurements } \\
\hline & $\overline{\mathrm{Kd}}$ & $\mathrm{mL} / \mathrm{g})$ & & $\mathrm{Kd}(\mathrm{I}$ & $\mathrm{mL} / \mathrm{g})$ \\
\hline $\mathrm{COC}$ & $\begin{array}{l}\text { Reasonably } \\
\text { Conservative }\end{array}$ & Upper-Limit & $\mathrm{COC}$ & $\begin{array}{l}\text { Reasonably } \\
\text { Conservative }\end{array}$ & Upper-Limit \\
\hline Ac & 255 & 4074 & $\overline{\mathrm{Ni}}$ & 257 & 404 \\
\hline $\mathrm{Ag}$ & $>233$ & $>1947$ & $\mathrm{~Pb}$ & $>11460$ & $>38751$ \\
\hline $\mathrm{Al}$ & 228 & 1930 & $\mathrm{Pm}$ & 255 & 4074 \\
\hline As & 55 & 592 & $\mathrm{Ra}$ & 336 & 392.7 \\
\hline $\mathrm{Ba}$ & 320 & 374 & $\mathrm{Se}$ & 219 & 267 \\
\hline $\mathrm{Be}$ & 45 & 181 & $\mathrm{Sr}$ & 1676 & 5518 \\
\hline $\mathrm{Cd}$ & 39 & 39 & $\mathrm{Tc}$ & 0.5 & 12.5 \\
\hline $\mathrm{Ce}$ & 255 & 4074 & $\mathrm{Tl}$ & 41 & 75 \\
\hline $\mathrm{Cm}$ & 255 & 4074 & $\mathrm{Th}$ & 115 & 2255 \\
\hline $\mathrm{Cr}$ & 58 & 2062 & $U$ & 170 & 6493 \\
\hline $\mathrm{Cu}$ & 67 & 290 & cis-1,2-Dichloroethene & 0 & 0.1 \\
\hline $\mathrm{Fe}$ & 199 & 2589 & Trichloroethene & 0.1 & 0.2 \\
\hline $\mathrm{Hg}$ & 4704 & 5725 & Carbon Tetrachloride & 0.2 & 0.2 \\
\hline $\mathrm{K}$ & 1.2 & 3.2 & Tetrachloroethene & 0.6 & 0.9 \\
\hline $\mathrm{Mn}$ & 268 & 3108 & Vinyl Chloride & 0 & 0.1 \\
\hline
\end{tabular}

In summary, this study provided technically defensible evidence for selecting several $\mathrm{Kd}$ values, especially for the inorganic $\mathrm{COCs}$, which are appreciably greater than present literaturederived values. These site-specific values will improve accuracy and remove some unnecessary 
conservatism in future transport and risk calculations associated with the TNX Outfall Delta Operable Unit. 


\section{Table of Contents}

1. INTRODUCTION ............................................................................................8

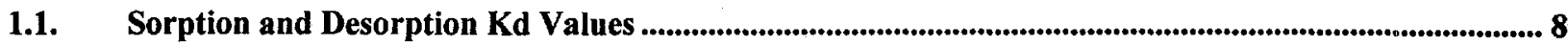

1.2. Selective Contaminants Desorption from Sediments.......................................................................... 9

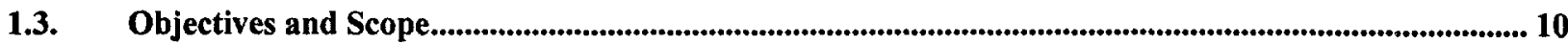

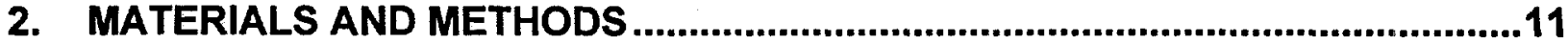

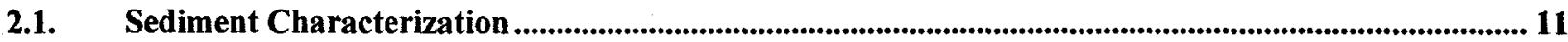

2.2. Overview of the Sequential Extraction Measurements .................................................................................. 12

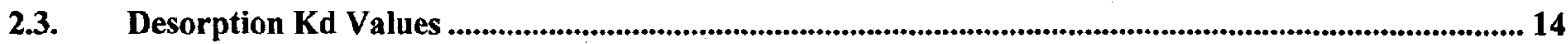

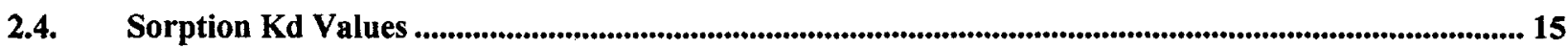

2.5. Organic Contaminant Kd Values Calculated from Water Partition Coefficients.................................. 16

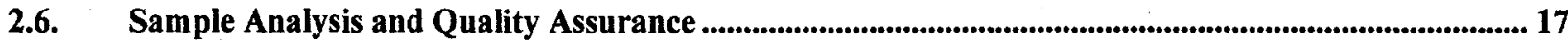

3. RESULTS AND DISCUSSION....................................................................17

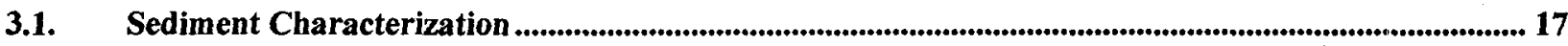

3.2. Desorption Kd Values for Inorganic Contaminants................................................................................. 21

3.3. Sorption Kd Values for Inorganic Contaminants.................................................................................... 24

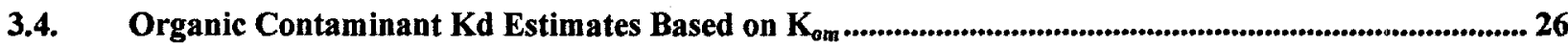

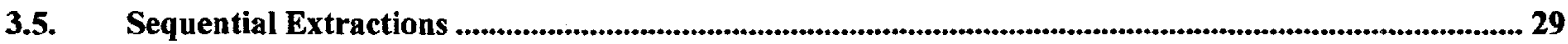

3.6. Contaminant Association to Various Sediment Particle Sizes................................................................33

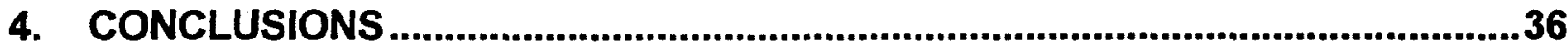

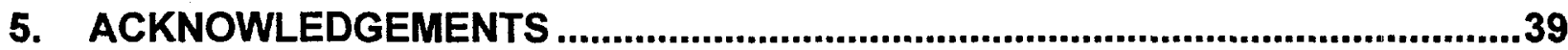

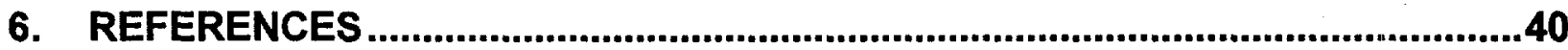

7. APPENDIX A: DETAILED SEQUENTIAL EXTRACTION PROCEDURE

8. APPENDIX B: DETAILED SORPTION KD PROCEDURE..................................49 
9. APPENDIX C: SUPPLEMENTAL DATA 


\section{Introduction}

\subsection{Sorption and Desorption Kd Values}

The distribution coefficient, or $\mathrm{Kd}$ value, is one of the simplest constructs that describes contaminant sorption to sediments. It is the ratio of the contaminant concentration sorbed to the solid phase divided by the contaminant concentration in the liquid surrounding the solid phase (Equation 1):

$$
K d=\frac{C_{\text {solid }}}{C_{\text {liquid }}}
$$

where $C_{\text {solid }}\left(\mathrm{M} \mathrm{kg}^{-1}\right)$ and $C_{\text {liquid }}\left(\mathrm{M} \mathrm{L}^{-1}\right)$ are the contaminant concentration in the solid and liquid phases, respectively. The $\mathrm{Kd}$ value is commonly used to define the retardation factor, which is the ratio of the average linear velocity of water $\left(\mathrm{m} \mathrm{s}^{-1}\right)$ divided by the average linear velocity of the contaminant $\left(\mathrm{m} \mathrm{s}^{-1}\right)$. The $\mathrm{Kd}$ value is related to the retardation factor ( $R f$, unitless) by the bulk density $\left(\rho_{b}, \mathrm{~kg} \mathrm{~m}^{-3}\right)$ and the porosity $\left(\eta, \mathrm{m}^{3} \mathrm{~m}^{-3}\right)$, as shown in Equation 2 (Valocchi 1984, Bouwer 1991):

$$
R f=\left(1+\frac{K d \rho_{b}}{\eta}\right)
$$

There are several implicit assumptions involved in using the Kd value in Equation 2 (reviewed by Bouwer 1991). Among these assumptions is that the rate of adsorption is equal to the rate of desorption. In natural sediments, this is rarely the case because desorption processes are almost always appreciably slower than the sorption process (Sposito 1994). Furthermore, the longer a contaminant is in contact with the sediment, the greater the sorption/desorption hysteresis. As the contaminant "ages" with the sediment, the contaminant becomes more refractory by 1) diffusing deeper into the structure of the solid phase, or 2) being buried under surface precipitated layers. This latter process is especially common in carbonate systems (Sposito 1994) and may also occur in $\mathrm{Fe}$ - and $\mathrm{Al}$-oxide systems, the system at the SRS. Consequently, $\mathrm{Kd}$ values measured via sorption laboratory methods typically are appreciably less than Kd values measured via desorption methods. The former technique typically does not capture the "aging" phenomenon.

$\mathrm{Kd}$ values measured by sorption methods, henceforth referred to as sorption $\mathrm{Kd}$ values, are measured and used appreciably more often than desorption methods. There are several reasons for this. Geochemists are often interested only in the mechanisms and the conditions affecting contaminant sorption; the ultimate use of their data is not for contaminant transport calculations. Another reason for measuring sorption $\mathrm{Kd}$ values is that it is appreciably easier to do than desorption $\mathrm{Kd}$ values. For sorption Kd values, a known concentration of the contaminant is added to an uncontaminated solid phase. Assumptions about the speciation of the spiked contaminant must be made. The difference in the aqueous phase concentration before and after 
equilibration with the solid phase is assumed to be the contaminant concentration sorbed to the solid phase, as illustrated in Equation 3.

$$
K d_{\text {sorption }}=\frac{\left(C_{i}-C_{f}\right) \times\left(\frac{V_{a q}}{M_{s e d}}\right)}{C_{f}}
$$

where $i$ and $C_{f}$ are the initial and final contaminant concentration in the aqueous phase, $\mathrm{V}_{\mathrm{aq}}$ is the volume of the aqueous phase, and $M_{\text {sed }}$ is the mass of the solid phase.

Desorption Kd values, as compared to sorption $\mathrm{Kd}$ values, capture many processes that are more important to contaminant transport. Most sorption processes occur in the time frame of seconds to weeks. Natural desorption processes occur in the time frame of years to hundreds of years, which is similar to the time frame of interest for most transport modeling efforts. Perhaps just as important, desorption, as compared to sorption, is often the rate limiting process governing geochemical behavior in sediments. This latter point is important because it implies that contaminant transport is more likely controlled by desorption than adsorption.

Unfortunately, desorption $\mathrm{Kd}$ values are appreciably more difficult to measure than sorption $\mathrm{Kd}$ values. The difficulty lies in defining the contaminant concentration associated with the solid phase, $\mathrm{C}_{\text {solid }}$ in Equation 1. As mentioned above, the $\mathrm{Kd}$ construct describes the linear and completely reversible sorption of a contaminant to a sediment. The term "linear" indicates that the aqueous contaminant concentration does not influence the degree of sorption. The term "reversible" indicates that the rate of sorption is equal to the rate of desorption. The value that is used in the numerator of a $\mathrm{Kd}, \mathrm{C}_{\text {solid, }}$, must reflect not the total amount of contaminant in the sediment, but the reversibly sorbed contaminant concentration. Contaminants that have become part of a mineral structure or have coprecipitated from solution have little chance of re-entering the aqueous phase. These refractory contaminants should not be included in $\mathrm{C}_{\text {solid }}$ or an unrealistically high $\mathrm{Kd}$ will be measured. Unfortunately, the totally reversibly sorbed fraction is appreciably more poorly defined than the total contaminant concentration associated with the solid phase.

\subsection{Selective Contaminants Desorption from Sediments}

It is common for a contaminant to sorb by several processes at the same time when put in contact with a natural heterogeneous sediment. Furthermore, the rate that a contaminant sorbs and desorbs from an assembly of solid phases in a natural sediment varies. For example, cation exchange generally occurs appreciably faster than precipitation (Sposito 1994). Also, sorption and desorption rates of many cation exchange reactions are almost identical (Serne et al. 1996), whereas sorption and desorption rates of surface complexation reactions typically exhibit a large hysteresis (Sposito 1994). 
Theoretically, when the Kd values is used to define the retardation factor (Equation 2), it almost exclusively describes contaminant sorption and desorption by cation exchange. However, sediment $\mathrm{Kd}$ values measured in the laboratory almost always include sorption by other processes. Thus, the operational definition of a $\mathrm{Kd}$ provided in Equation 3 is not theoretically correct because sorption processes, other than those that are reversible are measured by this technique.

Numerous studies have been conducted to identify extraction techniques that selectively desorb specifically defined sediment fractions (Tessier et al. 1979, Miller et al. 1986, Nirel and Morel 1990, Clark et al. 1996). Typically, contaminants are desorbed from sediments by a sequential series of progressively more-aggressive extractants. Each extractant targets either a particular sorption process, such as cation exchange, or a particular phase within the heterogeneous sediment sample, such as the organic or amorphous $\mathrm{Fe}$ oxide phase.

Among the more important sorptive phases in the sediments in the TNX Outfall Delta are amorphous and crystalline Fe/Al oxides, organic matter, and minerals (primarily quartz, kaolinite, hydroxy-interlayered vermiculite, and illites). Among the more important sorption mechanisms are:

- surface complexation onto $\mathrm{pH}$-dependent charge sites on $\mathrm{Fe}$ and $\mathrm{Al}$ oxides, natural organic matter, and kaolinite,

- cation exchange onto permanent charge sites of minerals, and

- coprecipitation into $\mathrm{Fe}$ and $\mathrm{Al}$ oxides.

\subsection{Objectives and Scope}

The objectives of this study were to:

1. measure in-situ $\mathrm{Kd}$ values for several inorganic constituents of concern (COCs),

2. calculate $\mathrm{Kd}$ values for several organic $\mathrm{COCs}$ using measured organic matter concentration data and literature-derived organic matter/water partition coefficients, $\mathrm{K}_{\mathrm{om}}$.

3. conduct sequential extractions to evaluate the environmental availability of COCs and to evaluate which sediment phases are responsible for sorption, and

4. determine if the COC concentrations are enriched in the smaller particles, thereby making it possible for mobile particulates, including colloids, to enhance $\mathrm{COC}$ transport at the site.

The COCs at this waste unit were aluminum, arsenic, barium, beryllium, cadmium, chromium, copper, iron, lead, manganese, mercury, nickel, selenium, silver, thallium, actinium, cerium, curium, potassium, promethium, radium, strontium, technetium, thorium, uranium, cis-1,2dichloroethene, trichloroethene, carbon tetrachloride, tetrachloroethene, and vinyl chloride. Samples from five contaminated and one uncontaminated sediment locations from the TNX Outfall Delta area were used in this studies. 


\section{Materials and Methods}

\subsection{Sediment Characterization}

Five contaminated and one uncontaminated (background:101, BG5-0) sediment from the TNX OD were used in this study (Table 1). The sediments were collected by a private contractor using a hand auger and delivered to our laboratory through standard Chain of Custody protocol. The contaminated sediments were selected because it was anticipated that they would have high contaminant concentrations based on contamination maps previously reported. Sediment 101, BG5-0, was collected from an uncontaminated portion of the study area. The sediment from the 0 to $0.4-\mathrm{ft}$ depth at this location consisted primarily of organic matter. This 0.4 to $1.4-\mathrm{ft}$ depth sample was selected because its higher mineral content was more typical of the contaminated sediments (Sediments 102-106). The criteria used for selecting the location and sampling depths of the contaminated samples was to obtain sediments that were highly contaminated with a wide range of contaminants. The total COC sediment concentration data reported in WSRCRP-98-4158, Rev. 0 ("RFI/RI with BRA for the TNX Outfall Delta, Lower Discharge Gully and Swamp Operable Unit," July 1999) was used as the basis for identifying the location and sampling depths. Finally, the reason for selecting sediment 105 was slightly different from the other contaminated samples. This location, D28, was selected because it was far from the point source and it had high contaminant concentrations, i.e., it was a "hot spot" far from the point source. This sample was used, along with the others, to evaluate whether particulate/colloid transport occurred at the site.

Table 1. Sediment identification and description.

\begin{tabular}{llll}
\hline $\begin{array}{l}\text { Chain of } \\
\text { Custody ID\# }\end{array}$ & $\begin{array}{l}\text { Chain of Custody } \\
\text { Description }\end{array}$ & Sample Depth (ft) & $\begin{array}{l}\text { Expt. ID\#, } \\
\text { Description }\end{array}$ \\
\hline 119329 & TNXOD-BG5K & 0.4 to 1.4 & 101, BG5-0 \\
119312 & TNXOD-A5K & 0 to 1 & 102, A5-0 \\
119316 & TNXOD-B5K & 0.5 to 1 & 103, B5-0.5 \\
119321 & TNXOD-C5K & 1 to 2 & 104, C5-1 \\
119322 & TNXOD-D28K & 0 to 1 & 105, D28-0 \\
119325 & TNXOD-B3K & 0.2 to 0.5 & 106, B3-0 \\
\hline
\end{tabular}

Soil $\mathrm{pH}$ was determined on 1:1 soil/water equilibrations (Thomas 1996). Soil organic C was determined by a modification of the unheated potassium dichromate method (Nelson and Sommers 1982). Cation and anion exchange capacities were determined by exchange with potassium and nitrate ions on sediments that were not $\mathrm{pH}$ adjusted, following the method of Sumner and Miller (1996). Iron oxide concentrations were determined by the dithionite reduction procedure (Loeppert and Inskeep 1996). Particle size distribution (sand, silt, and clay concentrations) was determined by the micropipette method (Miller and Miller 1987). Mineralogical semi-quantitative information was collected from X-ray diffraction analyses of the $<2-\mu$ m clay fraction that had been $\mathrm{H}_{2} \mathrm{O}_{2}$-treated for organic matter removal. X-ray diffraction 
was conducted on $\mathrm{Mg}$-saturated samples that had been sequentially analyzed at $25^{\circ} \mathrm{C}$, then again after the clay mount had been treated for $16 \mathrm{hr}$ at $65^{\circ} \mathrm{C}$, and then treatment for $16 \mathrm{hr}$ at $300^{\circ} \mathrm{C}$.

Analytical precision was $\leq 3 \%$ for the inductively coupled plasma-atomic emission spectroscopy, and $\leq 3 \%$ for $\mathrm{pH}$, specific conductivity, and organic $\mathrm{C}$.

\subsection{Overview of the Sequential Extraction Measurements}

An overview of the sequential extraction procedure used in this study is presented below. Details of the procedure are presented in Appendix A.

The sequential extraction method used in this study was taken from Miller et al. (1986) and is a modification of ASTM method D 5074-90 (ASTM 1990a) and ASTM D-3974-81 (ASTM 1990b). Six extractions (Table 2) were made from each of the 6 sediments. The mass extracted in the first four extraction steps were used to calculate the desorption $\mathrm{Kd}$ values (described below).

In an attempt to quantify the fraction of contaminant associated with the mineral matrix, some researchers have turned to selective extraction techniques (Amonette 1994, Tessier et al. 1979). Importantly, these selective or sequential extraction techniques have experimental limitations (Tessier et al. 1979, Nirel and Morel 1990). Problems with sequential extractions include incomplete extraction of trace elements or mineral surfaces, non-selectivity of extraction reagents for given soil phases, or readsorption of extracted contaminants onto other surfaces. Thus, individual sequential extraction phases may not adequately represent the discrete soil phase to which the contaminant is bound. The actual concentration extracted may only be assumed associated with a given operationally defined phase.

Table 2. Sequential Extractants

\begin{tabular}{|c|c|c|c|}
\hline $\begin{array}{l}\text { Se- } \\
\text { quence }\end{array}$ & Extractant: Chemical Composition & $\begin{array}{l}\text { Targeted Contaminant } \\
\text { Fraction }\end{array}$ & Ref. $^{\mathrm{a}}$ \\
\hline 1 & $\begin{array}{l}\text { Saturated Paste Extract: uncontaminated TNX surface } \\
\text { water }\end{array}$ & Aqueous & 1 \\
\hline 2 & $\begin{array}{l}\text { Dilute-acid Extract: dilute acetic acid }[0.44 \mathrm{M} \\
\left.\mathrm{CH}_{3} \mathrm{COOH}+0.1 \mathrm{M} \mathrm{Ca}\left(\mathrm{NO}_{3}\right)_{2}\right]\end{array}$ & Exchangeable & 2 \\
\hline 3 & $\begin{array}{l}\text { Organically Bound Extract: sodium pyrophosphate [0.1 } \\
\left.\mathrm{M}\left(\mathrm{Na}_{4} \mathrm{P}_{2} \mathrm{O}_{7}\right)\right]\end{array}$ & Bound to Organic Fraction & 2 \\
\hline 4 & $\begin{array}{l}\text { Amorphous Fe-oxide Extract: acidified ammonium } \\
\text { oxalate: pH } 3\left(0.175 \mathrm{M}\left(\mathrm{NH}_{4}\right)_{2} \mathrm{C}_{2} \mathrm{O}_{4}+0.1 \mathrm{M} \text { oxalic acid }\right. \\
\left(\mathrm{H}_{2} \mathrm{C}_{2} \mathrm{O}_{4}\right)\end{array}$ & $\begin{array}{l}\text { Associated with amorphous } \\
\text { Al- and Fe-oxide }\end{array}$ & 2 \\
\hline 5 & $\begin{array}{l}\text { Crystalline Fe-oxide: } 3.33 \% \text { Sodium dithionite in } 0.15 \\
\mathrm{M} \text { sodium citrate }+0.05 \text { citric acid buffer }\end{array}$ & $\begin{array}{l}\text { Associated with crystalline } \\
\text { Al- and Fe-oxide }\end{array}$ & 2 \\
\hline 6 & Aqua Regia: 1 part $\mathrm{HNO}_{3}: 3$ parts $\mathrm{HCl}: 1$ part $\mathrm{H}_{2} \mathrm{O}$ & Structural & 2 \\
\hline
\end{tabular}

"References: 1 = Miller et al. 1986, 2 = Rhoades 1996. 
The first extractant was the saturated paste. It was created by saturating a sediment with uncontaminated TNX surface water (collected about 1000-m north of the northern boundary of the TNXOD OU). The chemical composition of the uncontaminated surface water used in this study is presented in Table 3 . The water was left in contact with the sediment for one week and the water was recovered and analyzed for the COC. The second extractant, a dilute acidic acid solution, targeted the exchangeable fraction (Table 2). The COCs associated with the sediment organic matter were recovered by dissolving (oxidizing) the organic matter with $0.1-\mathrm{M}$ sodium pyrophosphate $\left(\mathrm{Na}_{4} \mathrm{O}_{2} \mathrm{O}_{7}\right)$. Sodium pyrophosphate is believed to oxidize the more readily oxidizable organic matter fraction, leaving organic matter that is harder to oxidize (i.e., organic matter high in lignin concentration). The COCs associated with the amorphous Fe-oxides were recovered by dissolving (reducing) this fraction with acidified ammonium oxalate. Ammonium oxalate will dissolve primarily the amorphous fraction, leaving behind the more crystalline fraction that requires a stronger reducing agent for it to dissolve. The COCs associated with the crystalline Fe-oxide fraction were recovered by dissolving the remaining solids with a stronger reducing agent than the ammonium oxalate, sodium dithionite. Finally, after the sediment had been treated with the five extracting solutions, it was totally digested. The COCs in the Aqua Regia digest were operationally assigned to be part of the mineral structure. This fraction is the least likely to contribute to the sorption/desorption process and contribute to COCs entering the mobile aqueous phase. 
Table 3. Chemical Composition of Uncontaminated Surface Water Collected from near the TNXOD OU.

\begin{tabular}{llllll}
\hline $\begin{array}{l}\text { Constituent } \\
(\mu \mathrm{g} / \mathrm{L})\end{array}$ & $\begin{array}{l}\text { Concentrationtration } \\
(\mathrm{mM})\end{array}$ & Constituent & $\begin{array}{l}\text { Concentration } \\
(\mu \mathrm{g} / \mathrm{L})\end{array}$ & $\begin{array}{l}\text { Concentration } \\
(\mathrm{mM})\end{array}$ \\
\hline $\mathrm{pH}$ & 5.1 (unitless) & & $\mathrm{Na}$ & 357.28 & 0.016 \\
$\mathrm{Al}$ & 9.12 & 0.00034 & $\mathrm{Ni}$ & 1.29 & $2.2 \mathrm{E}-05$ \\
$\mathrm{As}$ & $<0.18$ & & $\mathrm{Se}$ & $<0.61$ & \\
$\mathrm{Ba}$ & 64.87 & 0.0005 & $\mathrm{Si}$ & 4395 & 0.1565 \\
$\mathrm{Ca}$ & 3850 & 0.0962 & $\mathrm{Sr}$ & 33.98 & 0.00039 \\
$\mathrm{Ce}$ & 0.087 & $6.2 \mathrm{E}-07$ & $\mathrm{Th}$ & 0.013 & $5.69 \mathrm{E}-08$ \\
$\mathrm{Co}$ & 0.065 & $1.1 \mathrm{E}-06$ & $\mathrm{Tl}$ & 0.055 & $2.69 \mathrm{E}-07$ \\
$\mathrm{Cr}$ & $<0.92$ & & $\mathrm{U}$ & $<0.01$ & \\
$\mathrm{Cs}$ & 0.052 & $3.9 \mathrm{E}-07$ & $\mathrm{Chloride}$ & 2061 & 0.0598 \\
$\mathrm{Cu}$ & $<0.13$ & & Nitrate & 186 & 0.003 \\
$\mathrm{Eu}$ & 0.016 & $1 \mathrm{E}-07$ & Phosphate & $<100$ & \\
$\mathrm{Fe}$ & 99.3662 & 0.00178 & Nitrite & $<100$ & \\
$\mathrm{Hg}$ & 0.076 & $3.8 \mathrm{E}-07$ & Sulfate & 13690 & 0.214 \\
$\mathrm{~K}$ & 229.15 & 0.0058 & Inorganic C $<100$ & \\
$\mathrm{Mg}$ & 1117.89 & 0.046 & Organic C 6051 & 0.504 \\
$\mathrm{Mn}$ & 57.9 & 0.001 & Summation of Cations & 0.325 \\
& & & Summation of Anions & 0.277 \\
\hline
\end{tabular}

${ }^{\mathrm{a}}$ Surface water sample collected about $1000-\mathrm{m}$ north of the northern boundary of the operable unit.

\subsection{Desorption Kd Values}

Desorption $\mathrm{Kd}$ values $\left(K d_{\text {desorb }}\right)$ were measured from the six sediments used in the sequential extraction experiment (Table 1). The $\mathrm{Kd}$ values were calculated from the results of the first four extracts (Table 2) and were calculated using Equation 4:

$$
K d_{\text {desorb }}=\frac{C_{\text {Acid }}+C_{\text {Org }}+C_{A m F e O x}}{C_{\text {Sat.Paste }}}
$$

where $C_{A c i d} C_{O r g}$, and $C_{A m F e O x}$ are the contaminant concentrations in the solid phase extracted by the dilute-acid extract, organically bound extract, and the amorphous Fe-oxide extract $(\mu \mathrm{g} / \mathrm{g})$, respectively, and $C_{\text {Sat.Paste }}$ is the contaminant concentration in the aqueous phase extracted from the saturated paste extract $(\mu \mathrm{g} / \mathrm{mL})$. The contaminant concentration in the aqueous phase, $C_{\text {liquid, }}$ the denominator of the $\mathrm{Kd}$ term (Equations 1 and 4), was assumed to be equal to the amount of contaminant extracted by the saturated paste extract, i.e., TNX surface water left in contact with a field moist sample for 7 days. For additional details on how the saturated paste extract was prepared, see Appendix A. The $C_{\text {solid }}$ of the Kd term (Equations 1 and 4) was assumed to be 
equal to the exchangeable fraction plus the organic-bound fraction plus the amorphous Fe-oxide fraction as defined by the extracts presented in Table 2. The organic-bound extract, as the name implies, provides a measure of the amount of contaminant associated with the naturally occurring organic matter in the sediment by oxidizing the organic matter, thereby releasing the contaminant. The amorphous Fe-oxide extract provides a measure of the amount of contaminant associated with the non-crystalline, amorphous sesquioxides in sediments by partially reducing and solubilizing $\mathrm{Fe}$ (III)-oxides in the sediment to aqueous Fe(II). This extract is not strong enough to dissolve crystalline Fe-oxides. Aluminum oxides associated with the crystalline and amorphous Fe-oxide phases would also be extracted by these two treatments. The three extracts used to define $\mathrm{C}_{\text {solid }}$ for the maximum $\mathrm{Kd}$ term are expected not to recover contaminants that are occulted in silicates, aluminosilicates, crystalline Fe-oxides, or Mn-oxides. It was felt that only the exchangeable, organically bound, and amorphous Fe-oxide fractions would contribute to future contaminant plumes in this area. It is important to note, that the less contaminant assumed to be associated with $\mathrm{C}_{\text {solid, }}$, the more conservative (lower) the $\mathrm{Kd}$ estimate (Equation 1) will be.

\subsection{Sorption Kd Values}

Sorption Kd values were obtained for COCs for which desorption Kd values could not be measured. Desorption Kd values could not be calculated for some COCs because they had below detection-limit concentrations in the various desorption extractant solutions. These COCs were technetium, mercury, thallium, potassium, and barium (as a non-radioactive analog for radium). The batch sorption method used in these studies was based on ASTM method D 4319 (ASTM 1984). A detailed description of the method and the solutions made for these tests are presented in Appendix B. A brief description of the procedure follows.

The sediment used in this study was collected several hundred meters from the northern border of the TNXOD OU (Chain of Custody \# TNXOD-BG5K or SRTC Sediment \#101). Characterization of this sediment is presented in the Results and Discussion Section. For each element, approximately $0.35-\mathrm{g}$ of sediment were placed in $40-\mathrm{mL}$ centrifuge tubes. The sediments were then preequilibrated with 32 -hr washes of uncontaminated TNX surface water (Table 2). For $\mathrm{K}$, which already exists in the uncontaminated TNX surface water, the sediments used in the $\mathrm{K}$ sorption test was preequilibrated with $0.02 \mathrm{M} \mathrm{NaNO}_{3}$. Preequilibration of the sediments prior to conducting sorption tests has been shown to be essential (Kaplan and Serne 1999). Reactions, not of interest to the Kd measurement, such as precipitation, may occur as a result of the solution and sediment not being in equilibrium. The only solute that should be out of equilibrium during a sorption experiment is the solute of interest, in this case, the $\mathrm{Hg}, \mathrm{Ba}, \mathrm{Tl}$, $\mathrm{Tc}$, or $\mathrm{K}$.

After preequilibration, 35-mL of uncontaminated TNX surface water was spiked with $\mathrm{Ba}$, $\mathrm{Hg}, \mathrm{Tc}\left(\mathrm{as}^{99} \mathrm{TcO}_{4}\right)$ ), or $\mathrm{Tl}$ and $0.02 \mathrm{M} \mathrm{NaNO}_{3}$ was spiked with $\mathrm{K}$. These spiked solutions were added to the preequilibrated sediments. Two concentrations of the spiked solutions were made for each solute: 643 and $7637 \mu \mathrm{g} / \mathrm{L} \mathrm{Ba}$ (from $\mathrm{BaCl}_{2}$ ), 892 and $12,400 \mu \mathrm{g} / \mathrm{L} \mathrm{Hg}$ (from $\mathrm{Hg}\left(\mathrm{NO}_{3}\right.$ )$\mathrm{H}_{2} \mathrm{O}$ ), 1613 and $14900 \mu \mathrm{g} / \mathrm{L} \mathrm{K}$ (from $\mathrm{KNO}_{3}$ ), 1.5 and $15 \mu \mathrm{Ci} / \mathrm{L} \mathrm{Tc}$ (from ${ }^{99} \mathrm{TcO}_{4}{ }^{-}$in carrier free stock), and 92 and $9800 \mu \mathrm{g} / \mathrm{L} \mathrm{Tl}$ (from $\mathrm{TINO}_{3}$ ). The spiked solutions were permitted to 
equilibrate for three days prior to putting them in contact with the sediment. The soil-water suspensions were placed on a platform shaker for a week. After equilibration, the samples were centrifuged and then passed through a $0.45-\mu \mathrm{m}$ filter. The filtrates were then analyzed by General Engineering Laboratories (Charleston, SC) for the solute of interest: $\mathrm{Hg}$ by cold vapor atomic absorption, $\mathrm{K}$ by atomic absorption, $\mathrm{Tc}$ by liquid scintillation counting, and $\mathrm{Ba}$ and $\mathrm{Tl}$ by ICP-ES. The concentration data were then used in Equation 5 to calculate $\mathrm{Kd}_{\text {sorb }}$ values. Equation 5 accounts for the dilution of the initial spike solution by the interstitial water remaining in the sediment after the final preequilibrating wash (i.e., the unspiked water left in the tube after washing):

$$
K d_{\text {sorb }}=\frac{\left(\frac{\left(C_{\text {initial }} \times V_{\text {initial }}\right)-C_{\text {final }}\left(V_{\text {initial }}+V_{\text {int ersitital }}\right.}{M_{\text {sed }}}\right)}{C_{\text {final }}}
$$

where $V_{\text {interstitial }}$ is the volume of the interstitial solution left after the third pre-equilibration wash (L), $M_{\text {sed }}$ is the sediment mass $(\mathrm{g}), V_{\text {initial }}$ is the volume of the contaminant-amended solution added to the sediment $(\mathrm{L}), C_{\text {final }}$ is the contaminant concentration in the solution after contact with the sediment $(\mu \mathrm{g} / \mathrm{L})$, and $C_{\text {initial }}$ is the contaminant concentration of the contaminantamended solution $(\mu \mathrm{g} / \mathrm{L})$ added to the solids.

\subsection{Organic Contaminant Kd Values Calculated from Water Partition Coefficients}

$\mathrm{Kd}$ values for the organic constituents of concern were calculated, as opposed to measured directly, from organic matter/water partition coefficients, $\mathrm{K}_{\mathrm{om}}$ values ([mg contaminant $/ \mathrm{g} \mathrm{OM}] / \mathrm{mg}$ contaminant $/ \mathrm{mL}$ water). The relationship between $\mathrm{Kd}$ and $\mathrm{K}_{\text {om }}$ is presented in Equation 6,

$$
K d=f_{o m} K_{o m}
$$

where $f_{o m}$ is the weight fraction of natural organic mater $(\mathrm{kg} \mathrm{om} / \mathrm{kg}$ solid). There have been several theoretical and empirical relationships established between $K_{o m}$ and solubility and $K_{o m}$ and the octanol/water partition coefficient, $K_{o c}$ (Schwarzenbach et al. 1993). Two such Linear Free Energy Relationships (LLER's) to $K_{o m}$ 's were used in this study. For the chlorinated hydrocarbon contaminants, cis-1,2-dichloroethene, trichloroethene, carbon tetrachloride, and vinyl chloride, Equation 7 was used:

$$
\log \left(K_{o m}\right)=-0.7 \log \left(C^{s a t}\right)+0.35, \quad \mathrm{r}^{2}=0.99
$$

where $C^{\text {sat }}$ is the aqueous solubility of the neutral organic compound (Schwarzenbach et al. 1993). Equation 7 was established by using dozens of chlorinated hydrocarbon compounds. Thus, to calculate $\mathrm{Kd}$ values using Equations 7, one must measure the total organic carbon (natural organic matter consists of approximately $50 \%$ carbon) and literature values for $C^{\text {sat }}$. The 
total organic matter concentrations and the literature input values for each compound are presented in Section 3.0, Results and Discussion.

\subsection{Sample Analysis and Quality Assurance}

The standard QA practices described in the WSRC QA Manual 1Q were followed throughout this study. Commercial computer software packages (e.g. Microsoft Excel) were used for calculations. The software calculations were validated and verified by hand calculations. All calculations are considered (General Service) GS calculations. All M\&TE used in these experiments were calibrated by the Standards Laboratory. Calibration checks were performed by the section performing the work. Control of waste products from these activities were controlled by L1 Manual procedure 6.01 .

\section{Results and Discussion}

\subsection{Sediment Characterization}

Properties of the sediments used in this study are presented in Table 4. The textures of the sediments varied substantially. The clay content varied from $6.3 \%$ for Sediment 101 to $19.4 \%$ for Sediment 103 . The gravel fraction, $>2-\mathrm{mm}$, was very small for all sediments except, Sediment 102, which contained $21.2 \%$ gravel.

The sediment $\mathrm{pH}$ of the 6 sediments varied by just short of $2 \mathrm{pH}$ units, ranging from 4.00 to 5.78. The organic $\mathrm{C}$ concentrations were high, consistent with the fact that the sediments were collected from a forested wetland. The cation exchange capacity (CEC), a measure of the total number of cation exchange sites, was surprisingly low, considering that these sediments are high in organic C. Upland sediments on the SRS generally have CEC levels that are only fractionally lower than these values. The anion-exchange capacity (AEC) is a measure of the total number of anion exchange sites. These anion-exchange sites exist primarily on the organic matter and the Fe-oxides, but also exist to a smaller extent on the kaolinite particles. AEC ranged from $0.00 \pm$ $0.09 \mathrm{cmol}_{(-)} \mathrm{kg}^{-1}$ to $2.67 \pm 0.10 \mathrm{cmol}_{(-)} \mathrm{kg}^{-1}$.

Mineralogy of two fractions, $<2-\mu \mathrm{m}$ and $<0.5-\mu \mathrm{m}$, of Sediments 105 and 106 is presented in Table 5. The dominant minerals were kaolinite and hydroxy-interlayered vermiculite, comprising $>90 \%$ of the total mineral phase. Trace amounts of quartz, gibbsite, and illite made up the remainder of the mineral phase. This mineral composition is consistent with those previously reported (Ruhe and Matney 1990). The mineral composition of the $<0.5-\mu \mathrm{m}$ and the $<2-\mu \mathrm{m}$ fractions were remarkably similar (Figures 1 and 2). This finding is important in that it suggests that differences in contaminant association of these two size fractions would not be expected based on differences in mineralogy. For example, had the smaller fraction been dominated by illites or hydroxy-interlayered vermiculate, then greater contaminant association with the smaller fraction would be expected based on the greater sorption capacity of these minerals. 
Table 4. Sediment Characterization ${ }^{(a)}$

\begin{tabular}{lccccccccc}
\hline Sediment & $\begin{array}{c}<-\mathrm{mm} \\
(\%, \mathrm{wt})\end{array}$ & $\begin{array}{c}\text { Sand } \\
(\%, \mathrm{wt})\end{array}$ & $\begin{array}{c}\text { Silt } \\
(\%, \mathrm{wt})\end{array}$ & $\begin{array}{c}\text { Clay } \\
(\%, \mathrm{wt})\end{array}$ & pH & $\begin{array}{c}\text { Org. C } \\
(\mathrm{mg} / \mathrm{kg})\end{array}$ & $\begin{array}{c}\text { CEC } \\
\left(\mathrm{cmol}_{(+)} / \mathrm{kg}\right)\end{array}$ & $\begin{array}{c}\text { AEC } \\
(\mathrm{cmol}(-) / \mathrm{kg})\end{array}$ & $\begin{array}{c}\text { Fe-oxides }^{(6)} \\
(\%, \mathrm{wt})\end{array}$ \\
\hline 101 & $0.8 \pm 1.0$ & $79.4 \pm 2.1$ & $13.6 \pm 0.3$ & $6.3 \pm 0.8$ & $4.16 \pm 0.01$ & 1395 & $4.75 \pm 0.08$ & $1.56 \pm 0.17$ & 0.01 \\
102 & $21.2 \pm 6.3$ & $48.8 \pm 6.8$ & $23.6 \pm 1.6$ & $6.4 \pm 1.1$ & $4.00 \pm 0.08$ & 1493 & $8.96 \pm 0.09$ & $2.43 \pm 0.05$ & 0.08 \\
103 & $5.9 \pm 7.2$ & $52.9 \pm 8.2$ & $21.8 \pm 1.5$ & $19.4 \pm 0.6$ & $4.53 \pm 0.04$ & 1427 & $7.33 \pm 0.14$ & $0.00 \pm 0.06$ & 0.09 \\
104 & $1.5 \pm 1.1$ & $56.9 \pm 0.4$ & $31.4 \pm 0.0$ & $10.2 \pm 0.7$ & $5.26 \pm 0.01$ & 1167 & $9.31 \pm 0.37$ & $2.67 \pm 0.10$ & 0.10 \\
105 & $2.6 \pm 1.0$ & $59.4 \pm 4.4$ & $257 \pm 5.6$ & $12.3 \pm 0.2$ & $4.29 \pm 0.02$ & 1435 & $7.83 \pm 0.07$ & $1.90 \pm 0.04$ & 0.07 \\
106 & $0.5 \pm 0.1$ & $69.4 \pm 0.3$ & $19.9 \pm 0.4$ & $10.2 \pm 0.2$ & $5.78 \pm 0.06$ & 973 & $6.99 \pm 0.06$ & $1.50 \pm 0.00$ & 0.03 \\
\hline
\end{tabular}

(a) Analyses were conducted as duplicates or without duplication (where no standard deviation is presented).

(b) Fe-oxides: extracted by Na-dithionite from total sediment (an estimate of concentration of Fe-oxide coatings); reported as \% $\mathrm{Fe}_{2} \mathrm{O}_{3}$.

Table 5. Mineralogy of $<2$-um and $<0.5$-um Fractions ${ }^{(a)}$

\begin{tabular}{llcc}
\hline Sediment & Mineral & $\begin{array}{c}<2 \text {-um } \\
(\%, w t)\end{array}$ & $\begin{array}{c}<0.5 \text {-um } \\
(\%, w t)\end{array}$ \\
\hline 105 & Kaolinite & 68 & 75 \\
& Quartz & 0.8 & 0.2 \\
& HIV & 21 & 21 \\
& Illite & 24 & 1.6 \\
& Gibbsite & 4.7 & 2.2 \\
106 & Fe-oxides $\left(\right.$ as $\left.\mathrm{Fe}_{2} \mathrm{O}_{3}\right)$ & 2.2 & Not Measured \\
& Kaolinite & 0.1 & 79 \\
& Quartz & 78 & 0.2 \\
& HIV & 0.4 & 17 \\
& Illite & 17 & 2.6 \\
& Gibbsite & 1.9 & 1.9 \\
& Fe-oxides (as $\left.\mathrm{Fe}_{2} \mathrm{O}_{3}\right)$ & 2.3 & Not Measured \\
\hline
\end{tabular}

(a) Semi-quantitative estimates based on $\mathrm{x}$-ray diffraction analyses.

(b) HIV = hydroxy-interlayered vermiculite. 

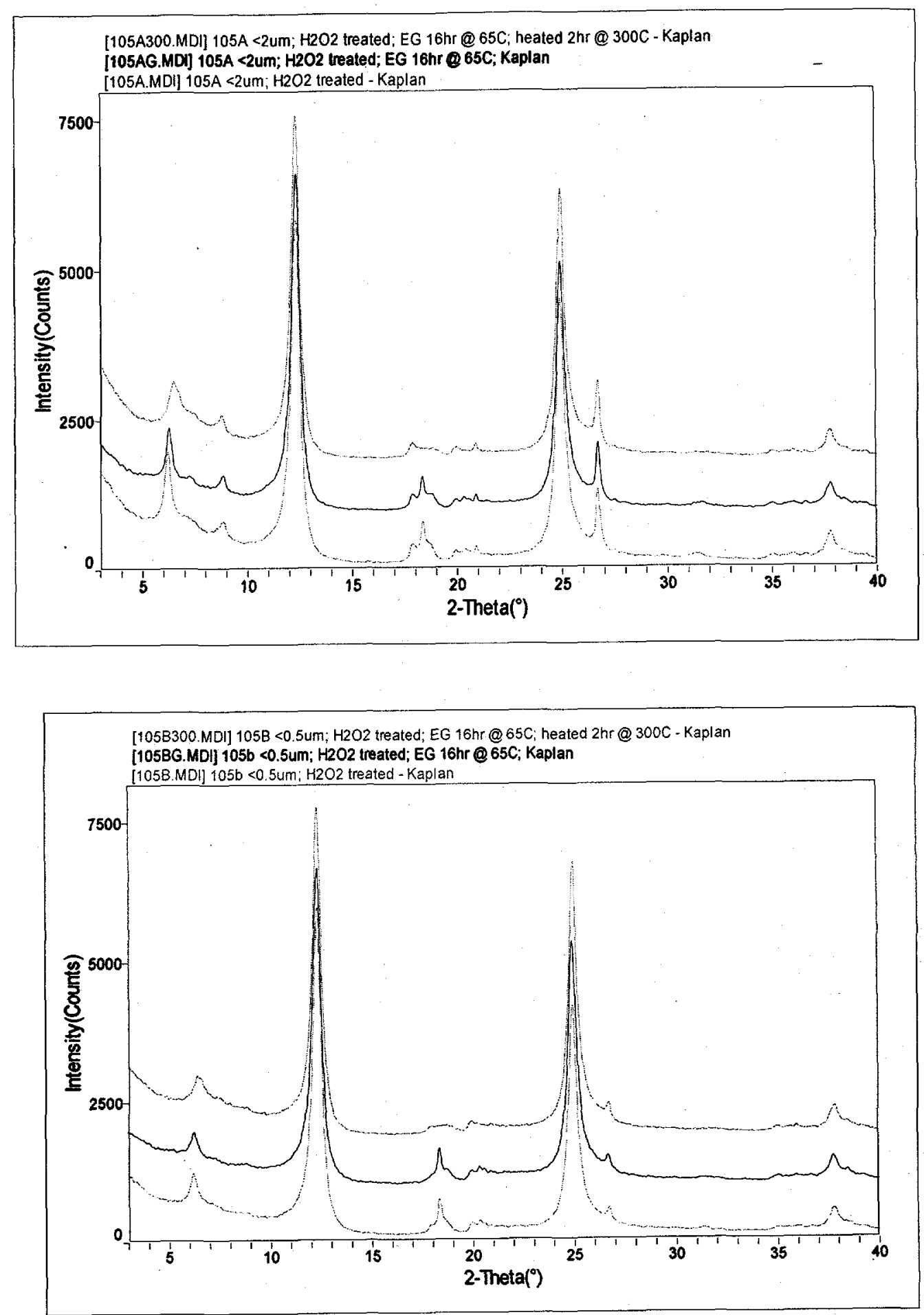

Figure 1. X-ray diffractograms of the $<2-\mu \mathrm{m}$ (top) and $<0.5-\mu \mathrm{m}$ (bottom) fraction of Sediment 105. For each plot, the bottom, middle, and top diffractograms are for a $25^{\circ}, 60^{\circ}$, and $300^{\circ} \mathrm{C}$ heat treatments, respectively. The peaks near $7^{\circ}, 9^{\circ}, 12^{\circ}, 18^{\circ}$, and $27^{\circ} 2$-theta are for hydroxyinterlayered vermiculite, illite, kaolinite, gibbsite, and quartz, respectively. 

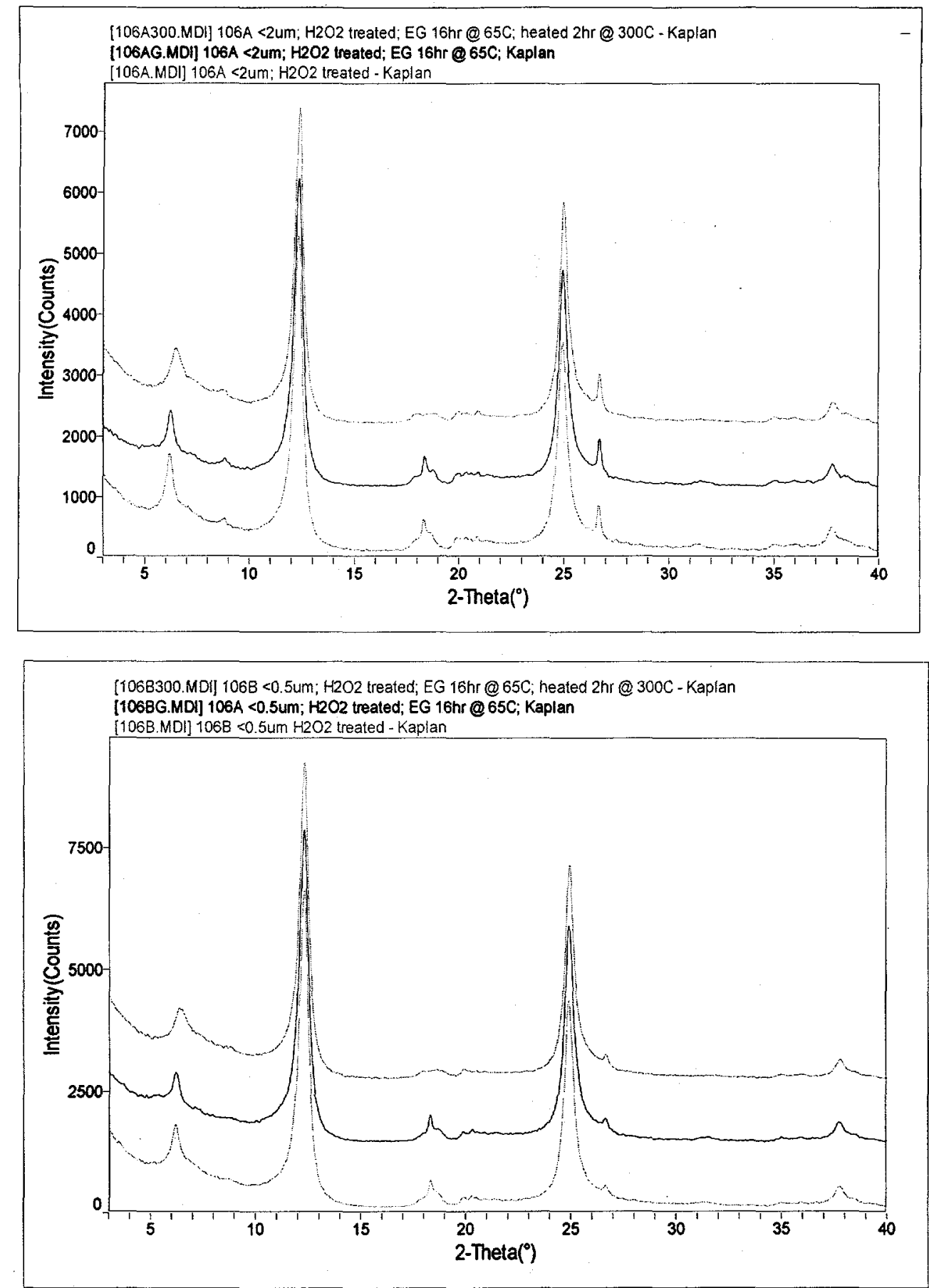

Figure 2. X-ray diffractograms of the $<2-\mu \mathrm{m}$ (top) and $<0.5-\mu \mathrm{m}$ (bottom) fraction of Sediment 106. For each plot, the bottom, middle, and top diffractograms are for a $25^{\circ}, 60^{\circ}$, and $300^{\circ} \mathrm{C}$ heat treatments, respectively. The peaks near $7^{\circ}, 9^{\circ}, 12^{\circ}, 18^{\circ}$, and $27^{\circ} 2$-theta are for hydroxyinterlayered vermiculite, illite, kaolinite, gibbsite, and quartz, respectively. 


\subsection{Desorption Kd Values for Inorganic Contaminants}

Desorption Kd values are presented in Table 7. The Conservative and Upper-limit Kd estimates presented in Table 7 are the lowest and the highest measured values. Kd values for Sediment 101, the uncontaminated sediment, are also included in this table, when their concentrations could be detected. The source of the contaminant is important because contaminants from natural sources may behave differently than those from anthropogenic sources, due to differences in concentration and speciation. Thus, in coming up with Reasonably Conservative and Upper Limit Kd values, the Kd values of Sediment 101, the background sediment, were not considered. No $\mathrm{Kd}$ values were calculated if $\mathrm{C}_{\text {solid }}$ and $\mathrm{C}_{\text {liquid }}$ had below detection values. Greater than $\mathrm{Kd}$ values were calculated if $\mathrm{C}_{\text {solid }}$ was measurable and $\mathrm{C}_{\text {liquid }}$ had a below detection value and a value of the detection limit was assumed for the $\mathrm{Cl}_{\text {liquid }}$. Concentration data are presented in Appendix C.

Among the inorganic $\mathrm{COCs}$, desorption $\mathrm{Kd}$ values were determined for $\mathrm{Ag}, \mathrm{Al}, \mathrm{As}, \mathrm{Ba}$, $\mathrm{Be}, \mathrm{Cd}, \mathrm{Ce}, \mathrm{Cr}, \mathrm{Cu}, \mathrm{Fe}, \mathrm{Mn}, \mathrm{Ni}, \mathrm{Pb}, \mathrm{Se}, \mathrm{Sr}, \mathrm{Th}$, and $\mathrm{U}$. COCs for which it was not possible to calculate $\mathrm{Kd}$ values due to below-detection-limit concentrations were $\mathrm{Ac}, \mathrm{Cm}, \mathrm{Hg}, \mathrm{Ra}, \mathrm{Tl}$, and $\mathrm{Pm}$. Below-detection-limit concentrations of $\mathrm{Hg}(0.010 \mathrm{mg} / \mathrm{L})$ were surprising in light of the fact that $\mathrm{Hg}$ concentration maps of the area indicate as much as $15 \mathrm{mg} / \mathrm{kg} \mathrm{Hg}$ existed in the areas where these sediment samples were collected. These latter COCs were not measured in an effort to meet schedule needs.

In general the $\mathrm{Kd}$ values are appreciably higher than the default literature $\mathrm{Kd}$ values used in contaminant transport calculations at the SRS. This can be attributed to: 1) desorption, rather than sorption being used to calculate the Kd values, 2) the high organic carbon concentrations of these sediments, and 3) the Kd values in these tables representing measured, site-specific values, instead of literature-derived conservative estimates, which are generally lower than measured values.

For several of the COCs, the variability was extremely high. This variability is likely real and not the result of experimental error. Among the more plausible causes for this variability is that the sediments appeared to differ greatly in texture, color, and organic matter content, hence they had different sorption properties (Table 4). Another probable cause for the variability is that the sources of the COCs may have been different, i.e., some COCs have natural and anthropogenic sources. Different sources may have different sorption processes. For instance, the concentrations of COCs from natural sources, such as $\mathrm{U}$ or Ce, may be limited by solubility constraints, whereas the concentration of the same COCs from anthropogenic sources, may be limited by (ad)sorption constraints.

An important caveat to this desorption data is that it is site-specific and that extrapolation to other sites is limited. Similar to traditional sorption Kd values, desorption Kd values are limited to systems with identical aqueous and solid phases. Thus, if conditions change at the field site, such as if the redox conditions change, it is expected that the $\mathrm{Kd}$ values for some of the 
COCs may change. Also, desorption Kd's are expected to change with time. So if a desorption $\mathrm{Kd}$ is measured shortly after a contaminant comes in contact with a sediment, the Kd value would be expected to be smaller than if it had been measured in a contaminated "aged" system. Consequently, the desorption $\mathrm{Kd}$ values reported in this report are likely greater than the $\mathrm{Kd}$ values that existed 30 years ago, when the contaminants first came into contact with the sediments. Finally, one important advantage of desorption $\mathrm{Kd}$ values that can not be over emphasized is that they do not require the experimenter make an assumption about the species existing in the system. In the case of sorption experiments, the experimenter must select a specie(s) to spike into the solid/liquid system. 
Table 7. Desorption Kd Values (mL/g; Equation 4)

\begin{tabular}{|c|c|c|c|c|c|c|c|c|}
\hline & \multicolumn{6}{|c|}{ Sediment } & \multirow[b]{2}{*}{$\begin{array}{r}\text { Reasonably } \\
\text { Conservative }^{(\mathrm{a})}\end{array}$} & \multirow[b]{2}{*}{$\begin{array}{r}\text { Upper } \\
\text { Limit }^{(b)}\end{array}$} \\
\hline & 101 & 102 & 103 & 104 & 105 & 106 & & \\
\hline$\overline{\mathrm{Ag}}$ & $>57$ & $>346$ & $>688$ & $>234$ & $>338$ & $>1947$ & $>233$ & $>1947$ \\
\hline As & & & 592 & 55 & & & 55 & 592 \\
\hline $\mathrm{Al}$ & 3369 & 1930 & 847 & 270 & 756 & 228 & 228 & 1930 \\
\hline $\mathrm{Ba}$ & 98 & 6045 & 1231 & 326 & 1055 & 517 & 326 & 6045 \\
\hline $\mathrm{Be}^{(\mathrm{d})}$ & 45 & & 181 & & 159 & & 45 & 181 \\
\hline $\mathrm{Cd}$ & & 39 & & & & & 39 & 39 \\
\hline $\mathrm{Ce}$ & & 2189 & 1523 & 255 & 4074 & 1361 & 255 & 4074 \\
\hline $\mathrm{Cr}$ & 2411 & 1475 & 643 & 58 & 2062 & 1126 & 58 & 2062 \\
\hline $\mathrm{Cu}$ & & 290 & 169 & 67 & 313 & 86 & 67 & 290 \\
\hline $\mathrm{Fe}$ & 4663 & 2589 & 1449 & 199 & 869 & 483 & 199 & 2589 \\
\hline Mn & 24 & 3108 & 1889 & 328 & 268 & 319 & 268 & 3108 \\
\hline $\mathrm{Ni}$ & & 257 & 404 & $>59$ & & & 257 & 404 \\
\hline $\mathrm{Pb}$ & & $>38751$ & $>21068$ & $>34511$ & $>37610$ & $>11460$ & $>11460$ & $>38751$ \\
\hline $\mathrm{Se}$ & 148 & 219 & 267 & 254 & 219 & 248 & 219 & 267 \\
\hline $\mathrm{Sr}$ & 1048 & 5518 & 3515 & 1676 & 2190 & 1886 & 1676 & 5518 \\
\hline Th & & & 1803 & 115 & 2255 & & 115 & 2255 \\
\hline U-238 & & 1237 & 1297 & 170 & 6493 & 2110 & 170 & 6493 \\
\hline
\end{tabular}

(a) Reasonably Conservative value is the lowest measured value among the contaminated sediments (Sediments $102-106$ ).

(b) Upper Limit Kd value is the largest measured value among the contaminated sediments (Sediments 102-106).

(c) Empty cells in table indicate that no desorption value could be measured due to below detection limit concentration in the sample.

(d) $\mathrm{Be} \mathrm{Kd}$ values are estimated based on Ca desorption data. The $\mathrm{Be} \mathrm{Kd}$ values reported in this table are half the measured $\mathrm{Ca}-\mathrm{Kd}$ values. Based on periodicity consideration, it is anticipated that these divalent IIA-group elements will behave very similarly; $\mathrm{Ca}$ will sorb slightly more strongly than Be.

Simple Pearson Correlation Coefficients (Table 8) were calculated using the desorption $\mathrm{Kd}$ values in Table 7 and the soil characterization data presented in Table 4. Additional correlation coefficients between the various soil properties are presented in Appendix Table C5. Before describing the results of these calculations, it is important to remember that significance of a correlation is dependent on the number of values included in the calculation, or more precisely, the degrees of freedom. Fewer the number of values included in a correlation calculation, the greater the correlation coefficient must be in order for it to be significant. Little credence is given to correlation coefficients with only degrees of freedom (correlation coefficients with Be-Kd and Th-Kd), even if they are significant. 
The significant correlation coefficients for the data presented in Table 8 have been printed in bold font. There were not many significant $(\mathrm{P}<0.05)$ correlations between the various $\mathrm{Kd}$ values and the soil characteristics. The positive correlation coefficients of $\mathrm{Ba}-\mathrm{Kd}, \mathrm{Mn}-\mathrm{Kd}$, and $\mathrm{Sr}-\mathrm{Kd}$ to $>2-\mathrm{mm}$ fraction is contrary to expectation and can not be explained. Generally, the greater the amount of large particles, the lower the surface area and therefore less sorption is expected. The positive correlation between $\mathrm{Cu}$ and organic $\mathrm{C}$ is well known and occurs because $\mathrm{Cu}$ forms an unusually strong complex to organic matter. Similar strong complexes with organic matter exist with Th and $\mathrm{Ce}$, yet significant correlation coefficients were not calculated for this data set.

Table 8. Pearson Correlation Coefficients Between Desorption Kd Values (Table 7) and Physical Soil Properties (Table 4) ${ }^{(a)}$ (excluded "greater than Kd values" from this Calculations.

\begin{tabular}{|c|c|c|c|c|c|c|c|c|c|c|}
\hline & d.f..$^{(a)}$ & $<2-\mathrm{mm}$ & Sand & Silt & Clay & $\mathrm{pH}$ & Org. C & CEC & AEC & Fe-oxides \\
\hline$<2-\mathrm{mm}$ & 5.00 & 1.00 & & & & & & & & \\
\hline Sand & 5 & -0.67 & 1.00 & & & & & & & \\
\hline Silt & 5 & 0.12 & -0.70 & 1.00 & & & & & & \\
\hline Clay & 5 & -0.23 & -0.38 & 0.21 & 1.00 & & & & & \\
\hline $\mathrm{pH}$ & 5 & -0.53 & 0.19 & 0.24 & 0.15 & 1.00 & & & & \\
\hline Organic C & 5 & 0.54 & -0.35 & -0.11 & 0.06 & $-0.97^{(b)}$ & 1.00 & & & \\
\hline CEC & 5 & 0.46 & -0.86 & 0.92 & 0.11 & 0.14 & -0.02 & 1.00 & & \\
\hline AEC & 5 & 0.21 & -0.07 & 0.46 & -0.76 & 0.03 & -0.13 & 0.47 & 1.00 & \\
\hline Fe-oxides & 5 & 0.40 & -0.94 & 0.87 & 0.45 & -0.05 & 0.24 & 0.89 & 0.13 & 1.00 \\
\hline Al-Kd & 5 & 0.22 & 0.44 & -0.71 & -0.53 & -0.71 & 0.56 & -0.62 & 0.01 & -0.57 \\
\hline Ba-Kd & 5 & 0.99 & -0.64 & 0.13 & -0.28 & -0.50 & 0.50 & 0.48 & 0.28 & 0.37 \\
\hline $\mathrm{Be}-\mathrm{Kd}$ & 2 & 0.86 & -1.00 & 0.89 & 0.91 & 0.86 & 0.94 & 0.95 & -0.49 & 1.00 \\
\hline $\mathrm{Ce}-\mathrm{Kd}$ & 4 & 0.15 & -0.04 & -0.22 & 0.00 & -0.61 & 0.56 & -0.25 & -0.03 & -0.11 \\
\hline $\mathrm{Cr}-\mathrm{Kd}$ & 5 & 0.02 & 0.53 & -0.67 & -0.45 & -0.59 & 0.43 & -0.64 & 0.02 & -0.65 \\
\hline $\mathrm{Cu}-\mathrm{Kd}$ & 4 & 0.57 & -0.48 & -0.13 & -0.13 & -0.89 & 0.83 & 0.08 & 0.07 & 0.20 \\
\hline Fe-Kd & 5 & 0.21 & 0.45 & -0.76 & -0.47 & -0.68 & 0.54 & -0.67 & -0.09 & -0.60 \\
\hline Mn-Kd & 5 & 0.94 & -0.75 & 0.11 & 0.08 & -0.44 & 0.51 & 0.45 & -0.09 & 0.49 \\
\hline Se-Kd & 5 & 0.04 & -0.66 & 0.65 & 0.67 & 0.55 & -0.36 & 0.67 & -0.21 & 0.71 \\
\hline Sr-Kd & 5 & 0.95 & -0.79 & 0.18 & 0.06 & -0.43 & 0.50 & 0.52 & -0.01 & 0.53 \\
\hline Th-Kd & 2 & 0.52 & 0.08 & -0.82 & 0.51 & -1.00 & 0.98 & -0.90 & -0.57 & -0.93 \\
\hline U238-Kd & 4 & -0.24 & 0.28 & -0.12 & 0.08 & -0.30 & 0.27 & -0.37 & -0.03 & -0.24 \\
\hline
\end{tabular}

(a) Excluded "greater than $\mathrm{Kd}$ values" from calculations.

(b) d.f. = degrees of freedom for variable. The degrees of freedom for the variables listed across the top of correlation matrix table are the same as those listed in this column.

(c) In Bold: Correlation coefficients greater than $0.95,0.88,0.81$ and 0.75 , with 2, 3, 4, and 5 degrees of freedoms, respectively, are significant at $\mathrm{P}<0.05$ level ( $5 \%$ probability level).

\subsection{Sorption Kd Values for Inorganic Contaminants}

Sorption $\mathrm{Kd}$ values were measured for COCs for which there was not sufficient concentrations in the contaminated sediments to measure a desorption $\mathrm{Kd}$ value. Sorption $\mathrm{Kd}$ values were measured for $\mathrm{Ba}, \mathrm{Hg}, \mathrm{K}, \mathrm{Tc}$, and $\mathrm{Tl}$. Barium $\mathrm{Kd}$ values were measured as an analog for radium $\mathrm{Kd}$ values. $\mathrm{Kd}$ values were measured using two initial contaminant spike 
concentrations. Since the concentrations of the COCs at the study site are more similar to the lower spike concentrations, the lower concentration Kd values are more relevant to TNXOD OU conditions. The higher concentration was included to evaluate the linearity of the sorption isotherm, i.e., to evaluate whether the concentration of the contaminant influences $\mathrm{Kd}$ values. As can be seen in Table 9, initial concentrations greatly affect $\mathrm{Ba}$ and $\mathrm{Hg} \mathrm{Kd}$ values, and have little affect on $\mathrm{K}, \mathrm{Tc}$, and $\mathrm{Tl} \mathrm{Kd}$ values.

Measured sorption $\mathrm{Hg}$ values were quite high. These values are consistent with $\mathrm{Hg}$ sorption Kd values measured with subsurface a sandy and a clayey sediment collected near the Ford Building Seepage Basin located on the SRS (Kaplan and Iversen 1999). Over a range of about 0.1 to $75 \mathrm{mg} / \mathrm{L} \mathrm{Hg}(\mathrm{II})$, the $\mathrm{Kd}$ values for the sand ranged between $\sim 1000$ to $\sim 2000 \mathrm{~mL} / \mathrm{g}$; the clay $\mathrm{Kd}$ values ranged from $\sim 1000$ to $\sim 8000 \mathrm{~mL} / \mathrm{g}$. Unlike the TNXOD OU surface sediments used in this report, the subsurface Ford Building sediments contained very low concentrations of organic matter. This is important, in that high $\mathrm{Hg}-\mathrm{Kd}$ values are commonly associated with sediments that have high organic matter.

The fact that some Tc sorption, albeit only small amounts, was measured is also noteworthy. In these sediments, the Tc sorption can likely be attributed to the presence of organic matter. The mechanism by which Tc sorbs to organic rich sediments has been attributed to the enhanced anion exchange capacity of such soils, and to the ability of the organic matter to reduce the $\mathrm{Tc}$ (VII) to the sparingly soluble $\mathrm{Tc}$ (IV) species. In this study, the more likely sorption mechanism appears to be anionic exchange because only 5 to $10 \%$ of the added $\mathrm{Tc}$ (VII) was removed from solution. Had the Tc(VII) been reduced, then one would expect that much more, perhaps all, of the $\mathrm{Tc}(\mathrm{VII})$ would be converted to $\mathrm{Tc}(\mathrm{IV})$, thereby leaving essentially no ${ }^{99} \mathrm{Tc}$ in the aqueous phase at the end of the sorption experiment.

Barium Kd values were measured by the sorption and desorption method. The desorption $\mathrm{Kd}$ values ranged from 326 to $6045 \mathrm{~mL} / \mathrm{g}$ (Table 7). The sorption Kd values ranged form 67 to $347 \mathrm{~mL} / \mathrm{g}$ (Table 9). The lower sorption Kd values are consistent with the notion that sorption $\mathrm{Kd}$ values do not account for the "aging" process between the contaminant and sediment. 
Table 9. Adsorption $\mathrm{Kd}$ Values for $\mathrm{Ba}, \mathrm{Hg}, \mathrm{K}, \mathrm{Tc}$, and $\mathrm{Tl}$

\begin{tabular}{|c|c|c|c|c|c|}
\hline & Element & $\begin{array}{r}\text { Initial Conc. } \\
(\mu \mathrm{g} / \mathrm{L})\end{array}$ & $\begin{array}{r}\mathrm{Kd} \\
(\mathrm{mL} / \mathrm{g})\end{array}$ & $\begin{array}{r}\text { Ave Kd } \\
(\mathrm{mL} / \mathrm{g})\end{array}$ & $\begin{array}{r}\text { Stdev. Kd } \\
(\mathrm{mL} / \mathrm{g}) \\
\end{array}$ \\
\hline \multirow[t]{6}{*}{$\mathrm{Ba}$} & & 643 & 374.14 & 347.04 & 26.94 \\
\hline & & & 346.69 & & \\
\hline & & & 320.27 & & \\
\hline & & 7637 & 73.46 & 67.30 & 5.36 \\
\hline & & & 63.71 & & \\
\hline & & & 64.73 & & \\
\hline \multirow[t]{6}{*}{$\mathrm{Hg}$} & & 892 & 5581.88 & 5337.12 & 552.63 \\
\hline & & & 4704.38 & & \\
\hline & & & 5725.09 & & \\
\hline & & 12400 & 187.07 & 187.48 & 4.73 \\
\hline & & & 192.40 & & \\
\hline & & & 182.97 & & \\
\hline \multirow[t]{7}{*}{$\mathrm{K}$} & & 1613 & 1.20 & 1.95 & 1.12 \\
\hline & & & 1.42 & & \\
\hline & & & 3.24 & & \\
\hline & & 14900 & 10.05 & 6.33 & 4.00 \\
\hline & & & 8.99 & & \\
\hline & & & 4.96 & & \\
\hline & & & 1.31 & & \\
\hline \multirow[t]{6}{*}{ Tc } & & $1.5 \mu \mathrm{Ci} / \mathrm{L}$ & 12.53 & 4.65 & 6.83 \\
\hline & & & 0.95 & & \\
\hline & & & 0.48 & & \\
\hline & & $15 \mu \mathrm{Ci} / \mathrm{L}$ & 3.60 & 3.14 & 3.80 \\
\hline & & & 6.69 & & \\
\hline & & & -0.87 & & \\
\hline \multirow[t]{6}{*}{$\mathrm{Tl}$} & & 942 & 67.15 & 61.21 & 17.81 \\
\hline & & & 41.19 & & \\
\hline & & & 75.29 & & \\
\hline & & 9800 & 32.88 & 32.86 & 2.20 \\
\hline & & & 35.05 & & \\
\hline & & & 30.65 & & \\
\hline
\end{tabular}

\subsection{Organic Contaminant Kd Estimates Based on $\mathbf{K}_{\mathbf{o m}}$}

Kd values for organic contaminants were calculated using an EPA-approved method (EPA 1996). The literature solubility values, octanol/water partition coefficients $\left(\mathrm{K}_{\mathrm{ow}}\right)$, organic matter/water partition coefficients $\left(\mathrm{K}_{\mathrm{om}}\right)$, and $\mathrm{Kd}$ values of the various organic compounds are presented in Tables 10 and 11 . In general, the $\mathrm{Kd}$ values are $\sim 0 \mathrm{~mL} / \mathrm{g}$. These are unexpectedly 
low values considering the high organic matter concentrations in these sediments. This may in part be attributed to the assumption associated with Equation 6 that the only mechanism by which the organic compounds sorb to the sediment is by partitioning to the organic matter (driven by enthalpy) and that no sorption to the mineral phase occurs. This assumption becomes increasingly compromised as the hydrophobicity and the nonpolarity of the compound decreases. Although Equations 6 and 7 are commonly used to estimate organic compound Kd values, they may not be appropriate for these soils and contaminants, given the dominance of the mineral phase and the nonpolar character of the COCs. It is recommended that measured $\mathrm{Kd}$ values, instead of calculated Kd values for these contaminants be collected to verify these results. 
Table 10. Kd Values for Organic Compounds in 6 Sediments Calculated from Organic Carbon Concentration and $\mathrm{K}_{\mathrm{om}}$ Data.

\begin{tabular}{|c|c|c|c|c|c|c|c|c|c|c|}
\hline \multirow[t]{2}{*}{ Compound } & \multirow{2}{*}{$\begin{array}{l}\text { Solubility } \\
-\log (\mathrm{mol} / \mathrm{L})\end{array}$} & \multirow{2}{*}{$\begin{array}{l}\log (\text { Kow) } \\
\text { (unitless) }\end{array}$} & \multirow[t]{2}{*}{$\operatorname{Ref}^{a}$} & \multirow{2}{*}{$\begin{array}{l}\log (\text { Kom }) \\
\text { From } \\
\text { Equation } 7\end{array}$} & \multicolumn{6}{|c|}{$\mathrm{Kd}(\mathrm{mL} / \mathrm{g})^{\mathrm{b}}$} \\
\hline & & & & & $\begin{array}{l}\text { Sediment } \\
101\end{array}$ & $\begin{array}{l}\text { Sediment } \\
102\end{array}$ & $\begin{array}{l}\text { Sediment } \\
103\end{array}$ & $\begin{array}{l}\text { Sediment } \\
104\end{array}$ & $\begin{array}{l}\text { Sediment } \\
105\end{array}$ & $\begin{array}{l}\text { Sediment } \\
106\end{array}$ \\
\hline cis-1,2-Dichloroethene & 1.442 & 1.86 & 1 & 1.36 & 0.1 & 0.1 & 0.1 & 0.1 & 0.1 & 0.0 \\
\hline Trichloroethene & 2.04 & 2.42 & 2 & 1.78 & 0.2 & 0.2 & 0.2 & 0.1 & 0.2 & 0.1 \\
\hline Carbon tetrachloride & 2.2 & 2.73 & 2 & 1.89 & 0.2 & 0.2 & 0.2 & 0.2 & 0.2 & 0.2 \\
\hline Tetrachloroethene & 3.04 & 2.88 & 2 & 2.48 & 0.8 & 0.9 & 0.9 & 0.7 & 0.9 & 0.6 \\
\hline Vinyl chloride & 1.35 & 0.6 & 2 & 1.30 & 0.1 & 0.1 & 0.1 & 0.0 & 0.1 & 0.0 \\
\hline
\end{tabular}

a Reference for Solubility of $\mathrm{K}_{\text {ow }}$ values: 1 = Howard 1991; 2 = Schwarzenbach et al. 1992.

${ }^{b}$ Fraction of organic matter in the sediment, $f_{\text {om }}(\mathrm{kg} \mathrm{om} / \mathrm{kg}$ sediment $)$, for Sediment $101=0.0028$, Sediment $102=0.0030$, Sediment $103=$ 0.0029 , Sediment $104=0.0023$, Sediment $105=0.0029$, and Sediment $106=0.0020$ (see Table 4).

Table 11. Statistical Description of the Organic Contaminant Kd Values Measured in Sediments 102, 103, 104,105 , and 106.

\begin{tabular}{|c|c|c|c|c|c|}
\hline Compound & Median & Minimum & Maximum & Average & Std. Dev. \\
\hline cis-1,2-Dichloroethene & 0.1 & 0.0 & 0.1 & 0.1 & 0.0 \\
\hline Trichloroethene & 0.2 & 0.1 & 0.2 & 0.2 & 0.0 \\
\hline Carbon tetrachloride & 0.2 & 0.2 & 0.2 & 0.2 & 0.0 \\
\hline Tetrachloroethene & 0.9 & 0.6 & 0.9 & 0.8 & 0.1 \\
\hline Vinyl chloride & 0.1 & 0.0 & 0.1 & 0.1 & 0.0 \\
\hline
\end{tabular}




\subsection{Sequential Extractions}

Sequential extractions (Table 2) were conducted on the six sediments collected from the TNXOD OU (Tables 1, 4, 5, and 6). Portions of the data generated from these extractions were used to calculate the desorption Kd values. Presented in Tables 12 and 13 are the percent concentrations of each COC. As mentioned in the Material and Methods section (Section 2), sequential extractions are designed to selectively recover certain fractions of the contaminant, depending on the fraction it is associated with (organic, amorphous Fe-oxide, crystalline $\mathrm{Fe}$ oxide, or structural) or the process it is sorbed by (cation or anion exchange). Additionally, the sequence of the extractions generally becomes increasingly more vigorous.

There are a number of results from this work that can be used as supporting information for the selection of $\mathrm{Kd}$ values for the operable unit. A brief description of the overall trends observed in Tables 12 and 13, are (Exch $=$ exchangeable, $\mathrm{Org}=$ organic, $\mathrm{AmFeOx}=$ amorphous Fe-oxide, $\mathrm{CrFeOx}=$ crystalline Fe-oxide, and Struct $=$ structural):

- Ag and As were evenly distributed between the $\mathrm{Org}, \mathrm{AmFeOx}$, and $\mathrm{CrFeOx}$ fractions. $\mathrm{Ag}$ is a "soft metal" and therefore tends to partition to organic matter. As exists as an anion, thus it is not surprisingly associated with phases that are dominated by a large $\mathrm{pH}$-dependent charge.

- Al was spread throughout, especially the Struct fraction. This was expected because $\mathrm{Al}$ exists in most minerals.

- Ba was found primarily in the exchangeable fraction. All elements in the IIA group in the periodic table ( $\mathrm{Be}, \mathrm{Mg}, \mathrm{Ca}, \mathrm{Sr}, \mathrm{Ba}$, and $\mathrm{Ra}$ ) sorb primarily by cation exchange and surface complexation to $\mathrm{Fe} / \mathrm{Al}$ oxides.

- Cd was associated primarily to Exch and Org fractions. These sites tend to sorb contaminants weakly.

- Ce was associated primarily to the Exch, Org, and Struct fractions.

- Cr was associated primarily to the Exch, Org, and AmFeOx fractions. These are the weaker sorbing sites. This is consistent with the notion that this contaminant exists primarily as an anion, $\mathrm{CrO}_{4}^{-}$, and not as the sparingly soluble species $\mathrm{Cr}$ (III).

- Co was associated primarily with the Exch and Org sites.

- Cu was associated primarily with the Struct and $\mathrm{CrFeOx}$ fractions.

- Fe and Mn were found in most of the fractions. This is expected because these elements are found naturally in many minerals. Fe was especially abundant in the Org fraction, whereas Mn was found primarily in the Exch fraction.

- Ni was especially abundant in the Exch and Struct fractions.

- Pb was almost exclusively found in the Struct fraction.

- Sr was associated with the Exch and Struct fractions. This is consistent with the observation that naturally occurring $\mathrm{Sr}$ is abundant in groundwater and is known to be in the structure of many minerals.

- Hg was found almost exclusively in the Struct fraction. As the footnote to Table 13 indicates, $\mathrm{AmFeOx}$ and $\mathrm{CrFeOx}$ fractions could not be determined because the strong reducing agents used in the extraction solutions would convert $\mathrm{Hg}^{2 \pm}($ liq) into 
$\mathrm{Hg}^{0}$ (gas). The loss of $\mathrm{Hg}$ gas would result in an experimental artifact that is difficult to account for without expensive experimental protocols. Although $\mathrm{AmFeOx}$ is considered an "available phase," as defined in Equation 4, it is this researchers belief that the vast majority, if not all, of the $\mathrm{Hg}$ resided in a fraction that was very difficult to recover. Inconclusive evidence in support of this belief is the $\mathrm{Hg}$ analysis of the solid phase left after the first five extracts (extractions through to $\mathrm{CrFeOx}$ ) had considerable amount of $\mathrm{Hg}$ still present, generally around $75 \%$ of the total $\mathrm{Hg}$. Thus, if one was to assume that no volatilization occurred, which is unlikely, then $>75 \%$ of the $\mathrm{Hg}$ was structural.

- TI was associated primarily to the Org fraction. This is consistent with its "soft base" chemical properties.

- Th, which existed in very high concentrations in the contaminated sediments, was associated primarily with the Org and the $\mathrm{AmFeOx}$ fractions. This has important implications for remediation.

- $\mathbf{U}$ was associated with the Org and Exch fractions. This suggests that the $U$ is not as strongly sorbed as many of the other contaminants, and that it will have a propensity to enter the mobile aqueous phase.

These results have important implications for remediation strategies. Assuming that the "exchangeable," "organic bound," and "amorphous Fe-oxide" fractions are more likely to enter the mobile aqueous phase or the biosphere, then $\mathrm{Cd}, \mathrm{Cr}, \mathrm{Co}, \mathrm{Tl}, \mathrm{Th}$, and $\mathrm{U}$ are more likely to be remeditated by phytoremediation or solvent extraction than $\mathrm{Cu}, \mathrm{Pb}$, and $\mathrm{Hg}$. Conversely, $\mathrm{Cu}, \mathrm{Pb}$, and $\mathrm{Hg}$ would make better, albeit not the only, candidate contaminants for monitored natural attenuation than $\mathrm{Cd}, \mathrm{Cr}, \mathrm{Co}, \mathrm{Tl}, \mathrm{Th}$, and $\mathrm{U}$. 
Table 12. Sequential Extraction Concentrations (\%).

\begin{tabular}{|c|c|c|c|c|c|c|c|c|c|c|c|}
\hline Sediment & Extractant & $\mathrm{Ag}$ & $\mathrm{Al}$ & As & $\mathrm{Ba}$ & $\mathrm{Be}$ & $\mathrm{Cd}$ & $\mathrm{Ce}$ & $\mathrm{Cr}$ & $\mathrm{Co}$ & $\mathrm{Cu}$ \\
\hline \multirow[t]{5}{*}{101} & Acid Extractable & 3 & 27 & 0 & 52 & (a) & 0 & 44 & 24 & 69 & 4 \\
\hline & Organic Fraction & 45 & 41 & 0 & 16 & & 0 & 20 & 40 & 24 & 12 \\
\hline & Amorph. Fe-oxide & 18 & 7 & 74 & 0 & & 0 & 0 & 37 & 0 & 0 \\
\hline & Cryst. Fe-oxide & 35 & 19 & 26 & 28 & & 0 & 3 & 0 & 0 & 26 \\
\hline & Structural & 0 & 6 & 0 & 4 & & 0 & 33 & 0 & 7 & 58 \\
\hline \multirow[t]{5}{*}{102} & Acid Extractable & 0 & 14 & 0 & 68 & 100 & 28 & 25 & 10 & 64 & 1 \\
\hline & Organic Fraction & 41 & 56 & 52 & 8 & 0 & 72 & 17 & 37 & 20 & 15 \\
\hline & Amorph. Fe-oxide & 22 & 8 & 37 & 0 & 0 & 0 & 0 & 13 & 7 & 4 \\
\hline & Cryst. Fe-oxide & 37 & 11 & 11 & 18 & 0 & 0 & 1 & 29 & 9 & 13 \\
\hline & Structural & 0 & 11 & 0 & 6 & 0 & 0 & 56 & 11 & 0 & 67 \\
\hline \multirow[t]{5}{*}{103} & Acid Extractable & 0 & 5 & 0 & 34 & & 0 & 14 & 8 & 79 & 14 \\
\hline & Organic Fraction & 39 & 31 & 51 & 19 & & 100 & 15 & 40 & 21 & 16 \\
\hline & Amorph. Fe-oxide & 28 & 3 & 37 & 0 & & 0 & 0 & 10 & 0 & 4 \\
\hline & Cryst. Fe-oxide & 33 & 7 & 12 & 33 & & 0 & 1 & 26 & 0 & 34 \\
\hline & Structural & 0 & 53 & 0 & 14 & & 0 & 70 & 15 & 0 & 32 \\
\hline \multirow[t]{5}{*}{104} & Acid Extractable & 0 & 7 & 13 & 48 & & 0 & 12 & 7 & 68 & 8 \\
\hline & Organic Fraction & 31 & 60 & 67 & 16 & & 0 & 16 & 39 & 32 & 16 \\
\hline & Amorph. Fe-oxide & 34 & 4 & 0 & 0 & & 0 & 0 & 12 & 0 & 2 \\
\hline & Cryst. Fe-oxide & 34 & 12 & 20 & 27 & & 0 & 2 & 27 & 0 & 51 \\
\hline & Structural & 0 & 17 & 0 & 9 & & 0 & 70 & 15 & 0 & 23 \\
\hline \multirow[t]{5}{*}{105} & Acid Extractable & 0 & 8 & 0 & 60 & & 100 & 27 & 16 & 72 & 8 \\
\hline & Organic Fraction & 0 & 22 & 37 & 11 & & 0 & 16 & 54 & 28 & 15 \\
\hline & Amorph. Fe-oxide & 60 & 3 & 44 & 0 & & 0 & 0 & 18 & 0 & 3 \\
\hline & Cryst. Fe-oxide & 40 & 6 & 19 & 19 & & 0 & 1 & 0 & 0 & 45 \\
\hline & Structural & 0 & 61 & 0 & 9 & & 0 & 56 & 12 & 0 & 29 \\
\hline \multirow[t]{5}{*}{106} & Acid Extractable & 0 & 17 & 0 & 52 & & 0 & 30 & 12 & 0 & 4 \\
\hline & Organic Fraction & 0 & 50 & 0 & 12 & & 100 & 15 & 38 & 33 & 9 \\
\hline & Amorph. Fe-oxide & 52 & 8 & 0 & 0 & & 0 & 0 & 18 & 0 & 0 \\
\hline & Cryst. Fe-oxide & 48 & 12 & 100 & 29 & & 0 & 1 & 22 & 0 & 73 \\
\hline & Structural & 0 & 12 & 0 & 7 & & 0 & 54 & 10 & 67 & 14 \\
\hline
\end{tabular}

(a) Empty Cells indicate that the constituent of concern was not detected in a particular fraction. 
Table 13. Sequential Extraction Concentrations.

\begin{tabular}{|c|c|c|c|c|c|c|c|c|c|c|c|}
\hline & & $\mathrm{Fe}$ & $\mathrm{Mn}$ & $\mathrm{Ni}$ & $\mathrm{Pb}$ & $\mathrm{Sr}$ & $\mathrm{Hg}$ & $\mathrm{Tl}$ & Th-232 & U-235 & U-238 \\
\hline \multirow[t]{5}{*}{101} & $\%$ Acid Extractable & 2 & 76 & 33 & 0 & 68 & 0 & 5 & 0 & 0 & $\overline{0}$ \\
\hline & $\%$ Organic Fraction & 61 & 7 & 16 & 0 & 1 & 0 & 38 & 61 & 0 & 9 \\
\hline & $\%$ Amorph. Fe-oxide & 10 & 10 & 0 & 0 & 0 & -- & 44 & 39 & 0 & 0 \\
\hline & $\%$ Cryst. Fe-oxide & 23 & 6 & 51 & 0 & 3 & -- & 13 & 0 & 0 & 0 \\
\hline & $\%$ Structural & 4 & 1 & 0 & 0 & 28 & 100 & 0 & 0 & 0 & 91 \\
\hline \multirow[t]{5}{*}{102} & $\%$ Acid Extractable & 5 & 59 & 51 & 2 & 46 & 0 & 12 & 1 & 32 & 26 \\
\hline & $\%$ Organic Fraction & 62 & 13 & 25 & 8 & 2 & 8 & 55 & 84 & 68 & 57 \\
\hline & $\%$ Amorph. Fe-oxide & 19 & 10 & 0 & 3 & 0 & - & 0 & 10 & 0 & 4 \\
\hline & $\%$ Cryst. Fe-oxide & 11 & 11 & 24 & 3 & 3 & -- & 34 & 5 & 0 & 2 \\
\hline & $\%$ Structural & 3 & 7 & 0 & 83 & 49 & 92 & 0 & 0 & 0 & 11 \\
\hline \multirow[t]{5}{*}{103} & $\%$ Acid Extractable & 6 & 15 & 54 & 1 & 43 & 0 & 0 & 1 & 44 & 36 \\
\hline & $\%$ Organic Fraction & 49 & 2 & 23 & 8 & 2 & 100 & 62 & 65 & 51 & 37 \\
\hline & $\%$ Amorph. Fe-oxide & 23 & 0 & 0 & 0 & 0 & -- & 0 & 15 & 0 & 6 \\
\hline & $\%$ Cryst. Fe-oxide & 20 & 0 & 23 & 2 & 3 & -- & 38 & 7 & 5 & 3 \\
\hline & $\%$ Structural & 3 & 83 & 0 & 89 & 52 & 0 & 0 & 12 & 0 & 17 \\
\hline \multirow[t]{5}{*}{104} & $\%$ Acid Extractable & 9 & 65 & 44 & 2 & 46 & 0 & 0 & 0 & 27 & 25 \\
\hline & $\%$ Organic Fraction & 64 & 12 & 25 & 8 & 2 & 4 & 62 & 78 & 70 & 57 \\
\hline & $\%$ Amorph. Fe-oxide & 8 & 0 & 0 & 0 & 0 & -- & 0 & 6 & 0 & 3 \\
\hline & $\%$ Cryst. Fe-oxide & 13 & 0 & 31 & 3 & 3 & -- & 38 & 7 & 3 & 2 \\
\hline & $\%$ Structural & 7 & 23 & 0 & 87 & 48 & 96 & 0 & 9 & 0 & 14 \\
\hline \multirow[t]{5}{*}{105} & $\%$ Acid Extractable & 3 & 57 & 40 & 5 & 45 & 0 & $\mathbf{0}$ & 1 & 29 & 26 \\
\hline & $\%$ Organic Fraction & 54 & 20 & 24 & 7 & 1 & 0 & 0 & 88 & 71 & 56 \\
\hline & $\%$ Amorph. Fe-oxide & 23 & 0 & 0 & 0 & 0 & -- & 0 & 7 & 0 & 5 \\
\hline & $\%$ Cryst. Fe-oxide & 15 & 0 & 36 & 2 & 2 & -- & 100 & 4 & 0 & 2 \\
\hline & $\%$ Structural & 5 & 23 & 0 & 86 & 51 & 100 & 0 & 0 & 0 & 12 \\
\hline \multirow[t]{5}{*}{106} & $\%$ Acid Extractable & 4 & 50 & 10 & 5 & 57 & 0 & 0 & 0 & 51 & 44 \\
\hline & $\%$ Organic Fraction & 64 & 25 & 7 & 8 & 1 & 0 & 72 & 91 & 49 & 41 \\
\hline & $\%$ Amorph. Fe-oxide & 17 & 17 & 0 & 0 & 0 & - & 0 & 7 & 0 & 3 \\
\hline & $\%$ Cryst. Fe-oxide & 8 & 0 & 83 & 4 & 3 & -- & 28 & 2 & 0 & 1 \\
\hline & $\%$ Structural & 6 & 7 & 0 & 83 & 38 & 100 & 0 & 0 & 0 & 11 \\
\hline
\end{tabular}

The amorphous Fe-oxide and the crystalline Fe-oxide fractions could not be determined for $\mathrm{Hg}$ because the strong reducing agent used in the extract would volatize the $\mathrm{Hg}$, thereby providing an experimental artifact. Thus the "Structural" fraction, in fact represent the sum of the "Amorphous Fe-oxide + Crystalline Fe-oxide + Structural" fractions. 


\subsection{Contaminant Association to Various Sediment Particle Sizes}

The total COC concentrations of the whole sediment, $<2-\mu \mathrm{m}$ fraction, and the $<0.5-\mu \mathrm{m}$ fraction were determined. The intent of this work was to determine whether the COCs were enriched in the small size fractions and to evaluate whether it is likely that the contaminants were moving with mobile particulates, including colloids. Sediment 102 was the most contaminated sediment, with the highest concentrations of $\mathrm{Cd}, \mathrm{Ce}, \mathrm{Co}, \mathrm{Cr}, \mathrm{Ni}$, and $\mathrm{Sr}$. Sediment 102 is a surface sample collected closest to the point source (Table 1). Compared to the concentrations in the background sediment, $\mathrm{Ag}, \mathrm{Cr}, \mathrm{Hg}, \mathrm{Ni}, \mathrm{Th}-232, \mathrm{U}-235$ and U-238 concentrations were especially high in the sediments collected from the contaminated region of the TNXOD OU. There was little or no evidence of $\mathrm{As}, \mathrm{Ba}, \mathrm{Be}, \mathrm{Cd}, \mathrm{Ce}, \mathrm{Co}, \mathrm{Cu}, \mathrm{Mn}$, and $\mathrm{Tl}$ contamination in these sediments.

In Tables 14 and 15 the $\mathrm{COC}$ concentrations of the six sediments are presented. Those sediments collected from the contaminated region of the TNXOD OU that had COC concentrations in the whole sediment that were twice the concentration in the background sample, Sediment 101, were considered contaminated for this evaluation. The critical value of $2 x$ the background concentration was selected arbitrarily. The sediments with $2 x$ background concentration levels of a COC are identified in Tables 14 and 15 with bold font. Tables 14 and 15 also include the number of sediments in which the $\mathrm{COC}$ concentration in the whole sediment $\left(\mathrm{COC}_{\text {whole }}\right)$ was twice that measured in Sediment $101\left(\mathrm{COC}_{\text {whole, Background }}\right) . \mathrm{COC}$ enrichment was defined for this study as existing when the COC concentration in the $<0.5-\mu \mathrm{m}$ fraction (coc0.5- $\mu \mathrm{m}$ ) was twice that measured in the whole sediment $\left(\mathrm{COC}_{\text {Whole }}\right)$. $\mathrm{COC}$ exclusion was defined for this study as existing when the $\mathrm{COC}$ concentration of the whole sediments was twice that of the $\mathrm{COC}$ concentration in the $0.5-\mu \mathrm{m}$ fraction. Based on these definitions, none of the COCs were enriched in $>50 \%$ of the contaminated sediments (bold in Tables 14 and 15). Cadmium, $\mathrm{Hg}$, and U-235 were excluded from $>50 \%$ of the contaminated sediments. This latter finding indicates that $\mathrm{Cd}, \mathrm{Hg}$, and $\mathrm{U}-235$ were primarily associated with the $>0.5-\mu \mathrm{m}$ fraction (on a mass basis, as opposed to a volume or surface area basis).

These findings suggest that none of the COCs are moving primarily via particulate/colloid facilitated transport. Importantly, these findings do not rule out colloids as a possible vector. Instead they indicate, that if colloids are involved, they are not likely the only vector responsible for contaminant movement.

These findings also have important implications for remediation strategies. Based on Tables 14 and 15, soil washing, which is often designed to remove the smaller size fraction of contaminated sediments, is not a likely candidate for remediating these sediments. Soil washing is especially effective when a majority of the contaminants are associated with a small volume and well-defined size fraction of the total contaminated sediment. This was not consistently the case for any of the COCs measured in these sediments. 
Table 14. Elemental Composition $(\mu \mathrm{g} / \mathrm{g}$ ) of the Whole, $<2-\mathrm{um}$, and $<0.5$-um Sediment Fraction and Comparison of COC Concentration in Whole Sediment versus in Background Sediment, Sediment 101

\begin{tabular}{|c|c|c|c|c|c|c|c|c|c|c|c|}
\hline Sediment & Fraction & $\mathrm{Ag}$ & $\mathrm{Al}$ & As & $\mathrm{Ba}$ & $\mathrm{Be}$ & $\mathrm{Cd}$ & $\mathrm{Ce}$ & $\mathrm{Cr}$ & $\mathrm{Co}$ & $\mathrm{Cu}$ \\
\hline \multirow[t]{3}{*}{$\overline{101}$} & Whole & $<0.0001$ & 1915 & 0.368 & 21.973 & 0.466 & $<0.00002$ & 19.400 & 2.819 & 0.987 & 30.038 \\
\hline & $<2 \mathrm{um}$ & 2.610 & 11495 & 0.863 & 108.62 & 2.156 & $<0.00004$ & 63.870 & 15.242 & 3.317 & 15.342 \\
\hline & $<0.5 \mathrm{um}$ & 3.602 & 10911 & 2.096 & 57.55 & 1.412 & $<0.0003$ & 44.633 & 16.246 & 3.931 & 0.0001 \\
\hline \multirow[t]{3}{*}{102} & Whole & $1.803^{(a)}$ & 6252 & 0.577 & 78.721 & 0.804 & 0.334 & 53.561 & 44.598 & 3.688 & 88.252 \\
\hline & $<2$ um & $<0.0002$ & 11427 & 1.057 & 85.842 & 1.154 & $<0.00006$ & 54.590 & 46.876 & 4.042 & 21.199 \\
\hline & $<0.5 \mathrm{um}$ & 2.814 & 8070 & 2.006 & 53.123 & 0.770 & $<0.0002$ & 41.754 & 39.138 & 3.043 & $<0.0001$ \\
\hline \multirow[t]{3}{*}{103} & Whole & $<0.0001$ & 2828 & 0.289 & 16.371 & 0.198 & $<0.00002$ & 11.278 & 30.654 & 1.225 & $\overline{48.478}$ \\
\hline & $<2$ um & 2.304 & 5893 & 1.059 & 36.026 & 0.469 & 0.1101 & 19.177 & 102.04 & 1.236 & 14.965 \\
\hline & $<0.5$ um & 0.9411 & 4990 & 1.565 & 24.403 & 0.355 & 0.0691 & 15.200 & 309.92 & 2.193 & $<0.0001$ \\
\hline \multirow[t]{3}{*}{104} & Whole & 0.729 & 2338 & 0.439 & 17.326 & 0.228 & 0.0139 & 10.338 & 66.264 & 0.876 & 57.986 \\
\hline & $<2 \mathrm{um}$ & 1.306 & 6788 & 0.955 & 25.187 & 0.290 & $<0.00004$ & 20.823 & 95.319 & 1.175 & 17.014 \\
\hline & $<0.5$ um & 0.739 & 5644 & 1.415 & 17.811 & 0.216 & $<0.00006$ & 15.970 & 69.664 & 0.796 & $<0.0001$ \\
\hline \multirow[t]{3}{*}{105} & Whole & 0.258 & 3371 & 0.508 & 15.821 & 0.154 & 0.0496 & 15.042 & 78.158 & 1.080 & 55.155 \\
\hline & $<2 \mathrm{um}$ & 1.144 & 9799 & 0.679 & 40.086 & 0.793 & 0.0905 & 35.992 & 34.937 & 1.420 & 9.547 \\
\hline & $<0.5$ um & 0.888 & 10585 & 1.214 & 39.995 & 0.780 & $<0.00008$ & 35.355 & 34.558 & 1.422 & 0.0001 \\
\hline \multirow[t]{3}{*}{106} & Whole & 0.3433 & 4847 & 0.398 & 28.616 & 0.522 & 0.0531 & 32.854 & 25.909 & 1.018 & 57.450 \\
\hline & $<2 \mathrm{um}$ & $<0.0001$ & 11781 & 0.639 & 50.418 & 0.677 & $<0.00003$ & 24.658 & 87.214 & 2.928 & 10.782 \\
\hline & $<0.5$ um & $<0.0002$ & 11917 & 1.110 & 45.254 & 0.625 & $<0.00007$ & 22.363 & 79.192 & 2.811 & 52.582 \\
\hline \multirow{2}{*}{\multicolumn{2}{|c|}{$\begin{array}{l}\text { Number of sediments with } \mathrm{COC}_{\text {Whole }} \\
\text { is }>2 \mathrm{x} \mathrm{COC}_{\text {Whole, Background. }} \\
\text { Number of sediments with enrich- } \\
\text { ment }\left(\mathrm{COC}_{0.5-\mu \mathrm{m}} \text { is }>2 \mathrm{x} \mathrm{COC}_{\text {Whole }}\right)\end{array}$}} & 4 & 2 & 0 & 1 & 0 & 3 & 1 & 5 & 1 & 1 \\
\hline & & 1 & 1 & 0 & 0 & 0 & 0 & 0 & 2 & 0 & 0 \\
\hline \multicolumn{2}{|c|}{$\begin{array}{l}\text { Number of sediments with exclusion } \\
\left(\mathrm{COC}_{\text {Whole }} \text { is }>2 \times \mathrm{COC}_{0.5-\mu \mathrm{m}}\right)\end{array}$} & 0 & 0 & 0 & 0 & 0 & 3 & 0 & 1 & 0 & 1 \\
\hline \multicolumn{2}{|c|}{$\begin{array}{l}\text { Number of sediments with no } \\
\text { enrichment or exclusion }\end{array}$} & 3 & 1 & 0 & 1 & 0 & 0 & 1 & 2 & 1 & 0 \\
\hline
\end{tabular}

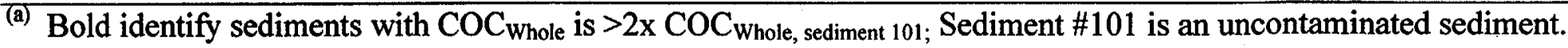


Table 15. Elemental Composition $(\mu \mathrm{g} / \mathrm{g})$ of the Whole, $<2$-um, and $<0.5$-um Sediment Fraction and Comparison of COC Concentration in Whole Sediment versus in Background Sediment, Sediment 101.

\begin{tabular}{|c|c|c|c|c|c|c|c|c|c|c|c|}
\hline Sediment & Fraction & $\mathrm{Fe}$ & $\mathrm{Hg}$ & $\mathrm{Mn}$ & $\mathrm{Ni}$ & $\mathrm{Pb}$ & $\mathrm{Sr}$ & $\mathrm{Tl}$ & Th 232 & $\mathrm{U}-235$ & U-238 \\
\hline \multirow[t]{3}{*}{$\overline{101}$} & Whole & 2635 & 0.034 & 84.28 & 1.869 & 4.093 & 1.464 & 0.117 & 2.709 & $<0.00002$ & 0.573 \\
\hline & $<2 \mathrm{um}$ & 14622 & 0.171 & 204.05 & 4.215 & 15.517 & 4.513 & 0.783 & 6.329 & $<0.00002$ & 1.830 \\
\hline & $<0.5$ um & 12288 & 0.303 & 94.36 & 0.000 & 18.977 & 2.191 & 1.345 & 24.686 & $<0.00002$ & 1.979 \\
\hline \multirow[t]{3}{*}{102} & Whole & $7533^{(\mathrm{a})}$ & 6.821 & 114.37 & 18.823 & 17.605 & 7.158 & 0.075 & 201.005 & 1.196 & 187.663 \\
\hline & $<2$ um & 11390 & 1.686 & 137.88 & 17.729 & 36.930 & 4.438 & 0.000 & 224.478 & 0.914 & 147.112 \\
\hline & $<0.5 \mathrm{um}$ & 9295 & 0.983 & 71.64 & 12.599 & 20.673 & 2.532 & 2.570 & 207.226 & $<0.00002$ & 127.713 \\
\hline \multirow[t]{3}{*}{103} & Whole & 1798 & 0.524 & 25.11 & 4.877 & 0.000 & 3.198 & 0.079 & 49.477 & 2.127 & 285.107 \\
\hline & $<2$ um & 12287 & 10.420 & 36.39 & 11.085 & 19.436 & 7.617 & 1.138 & 1452.734 & 2.426 & 427.905 \\
\hline & $<0.5 \mathrm{um}$ & 11365 & 5.626 & 35.21 & 162.929 & 17.277 & 4.710 & 1.368 & 1186.638 & 1.936 & 351.890 \\
\hline \multirow[t]{3}{*}{104} & Whole & 5490 & 9.454 & 20.84 & 9.781 & 10.459 & 3.608 & 0.087 & 694.863 & 1.808 & 329.144 \\
\hline & $<2 \mathrm{um}$ & 6383 & 6.759 & 27.62 & 6.858 & 18.868 & 2.379 & 0.771 & 849.770 & 4.540 & 640.345 \\
\hline & $<0.5 \mathrm{um}$ & 5555 & 5.747 & 16.28 & 4.951 & 16.535 & 1.683 & 1.017 & 802.642 & 3.447 & 503.490 \\
\hline \multirow[t]{3}{*}{105} & Whole & 3885 & 9.203 & 22.18 & 6.779 & 13.566 & 1.309 & 0.000 & 390.063 & 4.023 & 559.268 \\
\hline & $<2$ um & 6898 & 0.396 & 21.91 & 11.789 & 29.799 & 2.237 & 0.633 & 63.809 & 1.524 & 261.503 \\
\hline & $<0.5 \mathrm{um}$ & 7111 & 0.442 & 17.59 & 13.453 & 35.615 & 1.826 & 1.125 & 75.697 & 1.567 & 279.734 \\
\hline \multirow[t]{3}{*}{106} & Whole & 3794 & 0.636 & 13.52 & 13.098 & 24.896 & 2.588 & 0.133 & 29.169 & 1.583 & 287.712 \\
\hline & $<2$ um & 5847 & 0.848 & 52.85 & 11.694 & 21.530 & 6.447 & 0.000 & 164.818 & 4.796 & 646.347 \\
\hline & $<0.5 \mathrm{um}$ & 5397 & 0.745 & 45.66 & 14.265 & 21.379 & 4.268 & 0.000 & 158.384 & 4.722 & 633.242 \\
\hline \multicolumn{2}{|c|}{ Number of sediments where } & 2 & 4 & 0 & 5 & 4 & 3 & 0 & 5 & 5 & 5 \\
\hline \multirow{2}{*}{\multicolumn{2}{|c|}{$\begin{array}{l}\mathrm{COC}_{\text {Whole }} \text { is }>2 \mathrm{x} \mathrm{COC}_{\text {Whole, Background. }} \\
\text { Number of sediments where enrich- } \\
\text { ment }\left(\mathrm{COC}_{0.5-\mu \mathrm{m}} \text { is }>2 \times \mathrm{COC}_{\text {Whole }}\right)\end{array}$}} & & & & & & & & & & \\
\hline & & 0 & 1 & 0 & 1 & 1 & 1 & 0 & 2 & 1 & 1 \\
\hline \multicolumn{2}{|c|}{$\begin{array}{l}\text { Number of sediments where exclu- } \\
\text { sion }\left(\mathrm{COC}_{\text {Whole }} \text { is }>2 \times \mathrm{COC}_{0.5-\mu \mathrm{m}}\right)\end{array}$} & 0 & 2 & 0 & 0 & 0 & 1 & 0 & 1 & 3 & 1 \\
\hline \multicolumn{2}{|c|}{$\begin{array}{l}\text { Number of sediments with no } \\
\text { enrichment or exclusion }\end{array}$} & 2 & 1 & 0 & 4 & 3 & 1 & 0 & 2 & 1 & 3 \\
\hline
\end{tabular}

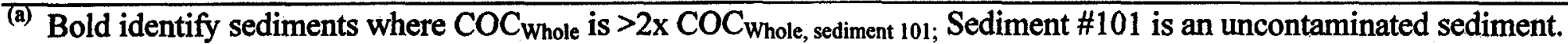




\section{Conclusions}

Kd values for constituents of concern (COCs) for the TNX Outfall Delta Operable Unit (TNXOD OU) were measured and calculated in this study. Kd values for inorganic COCs were measured using two techniques: desorption and (ad)sorption techniques. Kd values for organic COCs were calculated from an EPA-approved method based on the solubility of the COC and the concentration of organic matter in the sediment. Additionally, $\mathrm{Kd}$ values for some $\mathrm{COCs}$ were estimated, based on geochemical analogies. Geochemical analogies were necessary when various COCs were below detection limit in the contaminated sediments and were not included in the sorption-Kd tests. Ce-Kd values measured were used to estimate the $\mathrm{Ac}, \mathrm{Cm}$, and $\mathrm{Pm} \mathrm{Kd}$ values. These elements have similar geochemical (Kaplan and Serne 1999, Thibault et al. 1990) and chemical properties, including +3 oxidation states and large atomic weights. Desorption $\mathrm{Kd}$ values for $\mathrm{Ca}$ were used to estimate $\mathrm{Be}-\mathrm{Kd}$ values. Be existed in below detection limits in the five contaminated sediments. $\mathrm{Ca}$ is in the same period group as Be, Group IIA. Calcium would be expected to sorb slightly more strongly than $\mathrm{Be}$. Consequently, the $\mathrm{Be}-\mathrm{Kd}$ estimates were very conservatively set to half the measured $\mathrm{Ca}$ values. Finally, measured desorption $\mathrm{Ba}-\mathrm{Kd}$ values were used to estimate $\mathrm{Ra} \mathrm{Kd}$ values. Ba exists just above $\mathrm{Ra}$ in the IIA Group in the periodic table, and it is expected to sorb slightly less strongly to sediments than Ra. Hence, Ba would be expected to provide a conservative estimate of Ra sorption.

Reasonably Conservative and Upper Limit Kd values for each of the COCs are presented in Table 16. The sources of these data are also provided in the table. Reasonably Conservative values were the lowest measured or calculated (for organic $\mathrm{COCs}$ ) $\mathrm{Kd}$ values, whereas the Upper Limit values were the highest measured or calculated $\mathrm{Kd}$ values. In general, most of the in-situ $\mathrm{Kd}$ values were appreciably larger than default conservative $\mathrm{Kd}$ values used in previous contaminant transport calculations. In the case of the desorption experiments, the cause for the large values can in part be attributed to the contaminants having several years to "age" with the sediments. During the aging process, the sorbed contaminants may be incorporated into the structure of the solid phase or be buried on the solid phase beneath recently formed precipitates (e.g., Fe-oxide or carbonate coatings), thereby limiting re-entry into the mobile aqueous phase. The organic-COC Kd values were generally quite low. This may be attributed to the implicit assumption associated with the calculation that sorption occurs only by partitioning to the organic matter (driven primarily by enthalpy) and not to the mineral phase. This assumption is increasingly inaccurate as the hydrophobicity of organic solute and the proportion of mineral surfaces increases.

The sequential extraction experiment revealed that $\mathrm{Cu}, \mathrm{Hg}$, and $\mathrm{Pb}$ were strongly bound onto the sediment, providing supporting evidence for selecting large $\mathrm{Kd}$ values for these COCs. Conversely, $\mathrm{Cd}, \mathrm{Cr}, \mathrm{Co}$, and $\mathrm{Tl}$, tended to be associated with the "exchangeable" and "organically bound" fractions, providing supporting evidence for selecting lower Kd values for these COCs. Measurements were conducted of the COC concentrations in the whole sediment, the $<2-\mu \mathrm{m}$ fraction, and the $<0.5-\mu \mathrm{m}$ fractions. The motivation behind these measurements was to test the hypothesis that some of the less soluble COCs, such as Th and $\mathrm{Hg}$, may have been 
transported at the study site via mobile colloids. Among the most contaminated sediments, there was only sporadic evidence of contaminant-concentration enrichment in the smaller fractions. These data do not rule out the possibility that COCs may be moving via colloid transport, but do strongly suggest that colloids are not the only means for COC transport.

The sequential extraction and the $\mathrm{COC}$ concentration versus size fraction data have important implications for remediation strategies. Assuming that the "exchangeable," "organic bound," and "amorphous Fe-oxide" fractions are more likely to enter the mobile aqueous phase or the biosphere, then $\mathrm{Cd}, \mathrm{Cr}, \mathrm{Co}, \mathrm{Tl}, \mathrm{Th}$, and $\mathrm{U}$ are more likely to be remediated by phytoremediation or solvent extraction than $\mathrm{Cu}, \mathrm{Pb}$, and $\mathrm{Hg}$. Conversely, $\mathrm{Cu}, \mathrm{Pb}$, and $\mathrm{Hg}$ would make better candidate contaminants for monitored natural attenuation than $\mathrm{Cd}, \mathrm{Cr}, \mathrm{Co}, \mathrm{Tl}, \mathrm{Th}$, and $\mathrm{U}$. The $\mathrm{COC}$ versus size fraction data suggests that soil washing, which removes the smaller size fraction of contaminated sediments, would not be an effective strategy for remediating these sediments. Soil washing is especially effective when a majority of the contaminants are associated with a small volume of sediment existing in a narrow particle size range. This was not consistently the case for any of the COCs measured in this study.

In summary, this study provided technically defensible evidence for selecting several $\mathrm{Kd}$ values, especially for the inorganic COCs, which are appreciably greater than present literaturederived values. These site-specific values will improve accuracy and remove some unnecessary conservatism in future transport and risk calculations associated with the TNX Outfall Delta Operable Unit. 
Table 16. Reasonably Conservative and Upper-Limit Kd Values ( $\mathrm{mL} / \mathrm{g}$ ) Based on Values Measured or Calculated in this Study.

\begin{tabular}{|c|c|c|c|}
\hline & $\begin{array}{l}\text { Reasonably } \\
\text { Conservative }\end{array}$ & $\begin{array}{l}\text { Upper- } \\
\text { Limit }\end{array}$ & Data Source \\
\hline Ac & 255 & 4074 & Based on Desorption Test, using Ce as an analog \\
\hline $\mathrm{Ag}$ & $>233$ & $>1947$ & Desorption Test \\
\hline $\mathrm{Al}$ & 228 & 1930 & Desorption Test \\
\hline As & 55 & 592 & Desorption Test \\
\hline $\mathrm{Ba}$ & 320 & 374 & Adsorption Batch Test \\
\hline $\mathrm{Be}$ & 45 & 181 & Based on Desorption Test, using $\mathrm{Ca}$ as an analog \\
\hline $\mathrm{Cd}$ & 39 & 39 & Desorption Test \\
\hline $\mathrm{Ce}$ & 255 & 4074 & Desorption Test \\
\hline $\mathrm{Cm}$ & 255 & 4074 & Based on Desorption Test, using $\mathrm{Ce}$ as an analog \\
\hline $\mathrm{Cr}$ & 58 & 2062 & Desorption Test \\
\hline $\mathrm{Cu}$ & 67 & 290 & Desorption Test \\
\hline $\mathrm{Fe}$ & 199 & 2589 & Desorption Test \\
\hline $\mathrm{Hg}$ & 4704 & 5725 & Adsorption Batch Test \\
\hline $\mathrm{K}$ & 1.2 & 3.2 & Adsorption Batch Test \\
\hline $\mathrm{Mn}$ & 268 & 3108 & Desorption Test \\
\hline $\mathrm{Ni}$ & 257 & 404 & Desorption Test \\
\hline $\mathrm{Pb}$ & $>11460$ & $>38751$ & Desorption Test \\
\hline $\mathrm{Pm}$ & 255 & 4074 & Based on Desorption Test, using Ce as an analog \\
\hline $\mathrm{Ra}$ & 336 & 393 & Based on Adsorption Test, using $\mathrm{Ba}$ as an analog \\
\hline $\mathrm{Se}$ & 219 & 267 & Desorption Test \\
\hline $\mathrm{Sr}$ & 1676 & 5518 & Desorption Test \\
\hline Tc & 0.5 & 12.5 & Adsorption Batch Test \\
\hline $\mathrm{Tl}$ & 41 & 75 & Adsorption Batch Test \\
\hline Th & 115 & 2255 & Desorption Test \\
\hline $\mathrm{U}$ & 170 & 6493 & Desorption Test \\
\hline $\begin{array}{l}\text { cis-1,2- } \\
\text { Dichloroethene }\end{array}$ & 0 & 0.1 & Calculated from Literature Kow/Solubility Values \\
\hline Trichloroethene & 0.1 & 0.2 & Calculated from Literature Kow/Solubility Values \\
\hline $\begin{array}{l}\text { Carbon } \\
\text { Tetrachloride }\end{array}$ & 0.2 & 0.2 & Calculated from Literature Kow/Solubility Values \\
\hline Tetrachloroethene & 0.6 & 0.9 & Calculated from Literature Kow/Solubility Values \\
\hline Vinyl Chloride & 0 & 0.1 & Calculated from Literature Kow/Solubility Values \\
\hline
\end{tabular}




\section{Acknowledgements}

The laboratory work presented in this report was conducted by Cathy Coffey (Liquid Waste Processing Support), Gary Iversen (SCUREF), and Nathan Bell (ORISE). This document was reviewed by Gary Iversen and Miles Denham. This work was supported by the U.S. Department of Energy under contract with Westinghouse Savannah River Company (DE-AC09-89SR18035). 


\section{References}

Amonette, J. E., G. R. Holdren, K. M. Krupka, and C. W. Lindenmeier. 1994. Assessing the Environmental Availability of Uranium in Soils and Sediments. NUREG/CR-6232. PNL-9750. Pacific Northwest National Laboratory, Richland, Washington.

ASTM. 1990a. "Standard Practice for Preparation of Natural-Matrix Sediment Reference Samples for Major and Trace Inorganic Constituents Analysis by Partial Extraction Procedures." D 5074-90. In: The Annual Book of ASTM Standards. American Society for Testing and Materials, Philadelphia, Pennsylvania.

ASTM. 1990b. "Standard Practices for Extraction of Trace Elements from Sediments." D 397481. In: The Annual Book of ASTM Standards. American Society for Testing and Materials, Philadelphia, Pennsylvania.

Bower, H. 1991. "Simple Derivation of the Retardation Equation and Application to Preferential Flow and Macrodispersion." Ground Water 29: 41-46.

Clark, S. B., W. H. Johnson, M. A. Malek, S. M. Serkiz, and T. G. Hinton. 1996. "A Comparison of Sequential Extraction Techniques to Estimate Geochemical Controls on the Mobility of Fission Product, Actinide, and Heavy Metal Contaminants in Soils." Radiochimica Acta 74:173-179.

Drever, J. I. 1973. "The Preparation of Oriented Clay Mineral Specimens for X-ray Diffraction Analysis by A Filter-Membrane Peel Technique." Am. Mineral. 58:553-554.

EPA. 1996. Soil Screening Guidance: User's Guide, Second Edition. EPA/540/R-96/018 Office of Solid Waste and Emergency Response, Washington, DC.

Howard, P. H. 1990. Fate and Exposure Data for Organic Chemicals, Volume II. Lewis Publishers, Chelsea, Michigan.

Howard, P. H., S. Banerjee, K. H. Robillard. 1985. "Measurement of Water Solubilities, Octanol/Water Partition Coefficients, and Vapor Pressures of Commercial Phthalate Esters." Environmental Toxicology and Chemistry 4:653-661.

Kaplan, D. I., and G. M. Iversen. 1999. Mercury-Kd Values of Sediment Collected from the Ford Building Seepage Basin. WSRC-TR-99-00357. Westinghouse Savannah River Company, Aiken, SC.

Kaplan, D. I. and R. J. Serne. 1999. Geochemical Data Package for the Hanford Immobilized Low-Activity Tank Waste Performance Assessment (ILAW-PA). PNNL-13037. Pacific Northwest National Laboratory, Richland, WA. 
Miller, W. P., D. C. Martens, L. W. Zelazny, and E. T. Kornegay. 1986. "Forms of Solid Phase copper in Copper-enriched Swine Manure." Journal of Environmental Quality 15:69-72.

Miller, W. P. and D. M. Miller. 1987. "A Micro-Pipette Method for Soil Mechanical Analysis." Communications In Soil Sci., Plant Anal. 18(1) 1-15.

Nirel, P. M. V., and F. M. M. Morel. 1990. "Pitfalls of Sequential Extractions." Water Resources Research 24:1055-1056.

Rhoades, J. D. 1996. "Salinity: Electrical Conductivity and Total Dissolved Solids." In: Methods of Soil Analysis, Part 3, Chemical Methods. pp. 417-436. D. L. Sparks (ed). Soil Science Society of America Press, Madison, Wisconsin.

Ruhe, R. V. and E. A. Matney. 1980. Clay Mineralogy of Selected Sediments and Soils at the Savannah River Plant, Aiken, South Carolina, DP-MS-80-119, Water Resources Research Center and Department of Geology, Indiana University, Bloomington, IN.

Schwarzenbach, R. P., P. M. Gschwend, and D. M. Imboden. 1993. Environmental Organic Chemistry. Wiley Interscience, New York.

Schwertmann, U., and R. M. Taylor. 1989. Iron Oxides. pp.379-438. In: Dixon J.B. and S. B. Weed (eds.) Minerals in Soil Environments. $2^{\text {nd }}$ ed., SSSA Book Series No.1, Soil Science Society of America and American Society of Agronomy, Madison, Wisconsin.

Serne, R. J., and V. L. LeGore. 1996. Strontium-90 Adsorption-Desorption Properties and Sediment Characterization at the $100 \mathrm{~N}$-area. PNL-7145. Pacific Northwest National Laboratory, Richland, Washington.

Sposito, G. 1994. Chemical Equilibria and Kinetics in Soils. Oxford University Press, New York.

Sumner, M. E. and W. P. Miller. 1996. "Cation Exchange Capacity and Exchange Coefficients." pp.1201-1229. In: D. H. Sparks (ed.), Methods of Soil Analysis, Part 3, Chemical Methods, Soil Science Society of America and American Society of Agronomy, Madison, Wisconsin.

Thibault, D. H., M. I. Sheppard, and P. A. Smith. 1990. A Critical Compilation and Review of Default Soil Solid/Liquid Partition Coefficients, $K_{d}$ for use in Environmental Assessments. AECL-10125. Atomic Energy of Canada Limited, Pinawa, Manitoba, Canada.

Thomas, G. W. 1996. Soil pH and Soil Acidity. In: D. H. Sparks (ed.) Methods of Soil Analysis, Part 3, Chemical Methods, Soil Science Society of America and American Society of Agronomy, Madison, Wisconsin. 
Tessier, A., P. G. C. Campbell, and M. Bisson. 1979. "Sequential Extraction Procedure for the Speciation of Particulate Trace Metals." Analytical Chemistry. 51:844-851.

Valocchi, A. J. 1984. "Describing the Transport of Ion-exchange Contaminants Using an Effective Kd Approach." Water Resources Research. 20:499-503. 
7. Appendix A: Detailed Sequential Extraction Procedure 


\section{Materials}

Five contaminated and one uncontaminated (background:101, BG5-0) sediment from the TNX OD were used in this study (Table A1). These sediments were selected because it was anticipated that they would have high contaminant concentrations based on contamination maps previously reported. The sediments were collected by a private contractor and delivered to our laboratory through standard Chain of Custody protocol.

\begin{tabular}{|c|c|c|c|}
\hline $\begin{array}{l}\text { Chain of } \\
\text { Custody ID\# }\end{array}$ & $\begin{array}{l}\text { Chain of Custody } \\
\text { Description }\end{array}$ & Sample Depth (ft) & $\begin{array}{l}\text { Expt. ID\#, } \\
\text { Description }\end{array}$ \\
\hline 119329 & TNXOD-BG5K & 0.4 to 1.4 & 101, BG5-0 \\
\hline 119312 & TNXOD-A5K & 0 to 1 & $102, A 5-0$ \\
\hline 119316 & TNXOD-B5K & 0.5 to 1 & $103, \mathrm{~B} 5-0.5$ \\
\hline 119321 & TNXOD-C5K & 1 to 2 & $104, C 5-1$ \\
\hline 119322 & TNXOD-D28K & 0 to 1 & $105, \mathrm{D} 28-0$ \\
\hline 119325 & TNXOD-B3K & 0.2 to 0.5 & $106, \mathrm{~B} 3-0$ \\
\hline
\end{tabular}

- Uncontaminated surface water was collected from TNX wetland, north of the contaminated TNXOD OU.

- Acid Soluble Extract: $0.44 \mathrm{M} \mathrm{CH}_{3} \mathrm{COOH}+0.1 \mathrm{M} \mathrm{Ca}\left(\mathrm{NO}_{3}\right)_{2}$. Weighed out $11.07 \mathrm{~g}$ $\mathrm{Ca}\left(\mathrm{NO}_{3}\right)_{2}-4 \mathrm{H}_{2} \mathrm{O}$ and $12.6 \mathrm{~mL}$ of Glacial acetic acid into a $500 \mathrm{~mL}$ volumetric and diluted with Milli-Q water

- Organically Bound Extract: $0.1 \mathrm{M} \mathrm{Na}_{4} \mathrm{P}_{2} \mathrm{O}_{7}$. Weighed out $22.0302 \mathrm{~g}$ of $\mathrm{Na}_{4} \mathrm{P}_{2} \mathrm{O}_{7}-10 \mathrm{H}_{2} \mathrm{O}$ into a $500-\mathrm{mL}$ volumetric flask and diluted with Milli-Q water.

- Amorphous Fe-Oxide Extract (acidified ammonium oxalate, $\mathrm{pH}$ 3.): Prepared a solution of $0.175 \mathrm{M}$ ammonium oxalate[ $\left(\mathrm{NH}_{4}\right)_{2} \mathrm{C}_{2} \mathrm{O}_{4}+0.1-\mathrm{M}$ oxalic acid $\left.\left(\mathrm{H}_{2} \mathrm{C}_{2} \mathrm{O}_{4}\right)\right]$. Weighed out $12.435 \mathrm{~g}$ of $\left(\mathrm{NH}_{4}\right)_{2} \mathrm{C}_{2} \mathrm{O}_{4}-\mathrm{H}_{2} \mathrm{O}$ and $6.305 \mathrm{~g}$ of $\mathrm{H}_{2} \mathrm{C}_{2} \mathrm{O}_{4}-\mathrm{H}_{2} \mathrm{O}$ into $\sim 400 \mathrm{~mL}$ deionized water, adjusted to $\mathrm{pH} 3.0$ by adding $\mathrm{NH}_{4} \mathrm{OH}$ or $\mathrm{HCl}$, and diluted to $0.5 \mathrm{~L}$ final volume.

- Crystalline Fe-oxide Extract (Citrate buffer; $0.15 \mathrm{M} \mathrm{Na}$-citrate + $0.05 \mathrm{M}$ Citric acid): Bring $22.06 \mathrm{~g} \mathrm{Na}$ citrate $\left(\mathrm{C}_{6} \mathrm{H}_{5} \mathrm{Na}_{3} \mathrm{O}_{7}-2 \mathrm{H}_{2} \mathrm{O}\right)$ and $5.25 \mathrm{~g}$ citric acid $\left(\mathrm{C}_{6} \mathrm{H}_{8} \mathrm{O}_{7}-\mathrm{H}_{2} \mathrm{O}\right)$ up to $500 \mathrm{~mL}$ with $\mathrm{H}_{2} \mathrm{O}$.

- Aqua Regia: 1 part $\mathrm{HNO}_{3}: 3$ parts $\mathrm{HCl}$ plus 1 part water.

\section{Saturated Paste Extracts}

1. Gravimetrically determined the moisture content of the sediments.

In triplicate, added $\sim 10-\mathrm{g}$ of sediment to tared aluminum weighing boats.

Left in hood to air-dry until weights did not change.

Calculate \% Air-dry weight as: \% Air-dry weight $=\left(1-\left[\left(\mathrm{W}_{i}-\mathrm{W}_{f}\right) / \mathrm{W}_{\mathrm{i}}\right]\right) * 100$.

2. Made a saturated paste using the procedure of Rhoades (1996). 
Added $600-\mathrm{mL}$ of field moist sediment into a tared, 1-L glass beaker.

3. Weighed moist sediment and beaker.

4. Added $<0.45-\mu \mathrm{m}$ filtered TNX surface water while stirring until sediment was nearly saturated.

5. Allowed the mixture to stand covered for several hours.

6. The criteria for a saturated paste were as follows:

- glistened as it reflects light,

- flowed slightly when the container is tipped,

- slid freely and cleanly off a smooth spatula, and

- consolidated easily by tapping or jarring the container after a trench is formed in the paste.

7. Upon attainment of saturation, weighed the container plus contents.

8. Covered samples with parafilm and let sample stand for 7 additional days.

9. Transferred paste to a filter funnel fitted with a filter paper. Filtered and saved filtrate and solids for subsequent analyses.

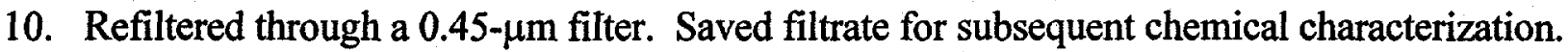

\section{Acid Soluble Extraction}

1. The following extractions were conducted in duplicate. For each sediment, weighed 1.0-g dry weight into tared, 35-mL centrifuge tubes. Recorded actual weight of "Tare + sed. dry wt. at start of acid soluble fraction."

2. Added 30-mL acid-soluble extraction solution to each tube.

3. Weighed sample and recorded "Tare + wet sed. + extract wt. for acid soluble fraction."

4. Placed on shaker for 1 day.

5. Centrifuged for $20 \mathrm{~min}$ at $6000 \mathrm{rpm}$.

6. Recovered supernate.

7. Pass supernate through a $0.45-\mu \mathrm{m}$ filter. Saved filtrate for subsequent chemical characterization.

8. Added $20 \mathrm{~mL}$ of $0.0125 \mathrm{Ca}\left(\mathrm{NO}_{3}\right)_{2}$ wash solution to each tube.

9. Mixed by hand for $1 \mathrm{~min}$.

10. Centrifuged for $20 \mathrm{~min}$ at $6000 \mathrm{rpm}$.

11. Discarded aqueous.

\section{Organic Extraction}

1. The following extractions were conducted in duplicate. Recorded weight of "tube and sed. wet weight for organic fraction."

2. Added $30 \mathrm{~mL}$ organically bound extractant to each tube.

3. Weighed sample and recorded "Tare + wet sed. + extract wt. for organic bound fraction."

4. Placed on shaker for 1 day.

5. Centrifuged for $20 \mathrm{~min}$ at $6000 \mathrm{rpm}$.

6. Recovered supernate. 
7. Pass supernate through a $0.45-\mu \mathrm{m}$ filter. Save this solution for subsequent chemical characterization.

8. Added $20 \mathrm{~mL}$ of $0.0125 \mathrm{Ca}\left(\mathrm{NO}_{3}\right)_{2}$ wash solution to each tube.

9. Mixed by hand for $1 \mathrm{~min}$.

10. Centrifuge for $20 \mathrm{~min}$ at $6000 \mathrm{rpm}$.

11. Discarded aqueous.

\section{Amorphous Fe-Oxide Extraction}

1. The following extractions were conducted in duplicate. Wrapped each tube in aluminum foil to avoid exposure to light. Recorded weight of "tube and sed. wet wt. for Amorphous Fe-Oxide fraction."

2. Added 30-mL Amorphous Fe-Oxide Extract to each tube. Minimized amount of light that came into contact with the suspensions by keeping the lights low, the samples in aluminum foil, and the samples in opaque boxes.

3. Weighed sample and recorded "Tare + wet sed. + extract wt. for amorphous Fe-oxide fraction."

4. Placed on shaker for $30 \mathrm{~min}$.

5. Centrifuge for $20 \mathrm{~min}$ at $6000 \mathrm{rpm}$.

6. Recovered supernate.

Pass supernate through a $0.45-\mu \mathrm{m}$ filter. Save solution for subsequent chemical characterization. 8. Added $20 \mathrm{~mL}$ of $0.0125 \mathrm{Ca}\left(\mathrm{NO}_{3}\right)_{2}$ wash solution to each tube.

9. Mixed by hand for $1 \mathrm{~min}$.

10. Centrifuged for $20 \mathrm{~min}$ at $6000 \mathrm{rpm}$

11. Discarded aqueous.

\section{Crystalline Fe-oxide Extraction}

1. Record weight of "tube and sed. wet weight for Crystalline. Fe-oxide" in Table A2.

2. Add 15-mL citrate buffer to each tube.

3. Add 0.75-g sodium dithionite (or sodium hydrosulfite, $\mathrm{Na}_{2} \mathrm{~S}_{2} \mathrm{O}_{4}, \mathrm{~F} . \mathrm{W} .=174.1$ ) to each test tube.

4. Shake by hand for $15 \mathrm{sec}$.

5. Weigh sample and record "Tare + wet sed. + extract wt. for Crystalline Fe-oxide fraction."

6. Put in water bath shaker for $30 \mathrm{~min}$ at $50^{\circ} \mathrm{C}$. Dry tubes when done.

7. Centrifuge for $10 \mathrm{~min}$ at $6000 \mathrm{rpm}$.

8. Recover supernate.

9. Pass through a $0.45-\mu \mathrm{m}$ filter.

10. Add $75-\mu \mathrm{L}$ of Ultrex (or Ultra Pure) $\mathrm{HNO}_{3}$ to each tube to preserve sample for analyses.

11. Add $20 \mathrm{~mL}$ of $0.0125 \mathrm{Ca}\left(\mathrm{NO}_{3}\right)_{2}$ wash solution to each tube.

12. Mix by hand for $1 \mathrm{~min}$.

13. Centrifuge for $10 \mathrm{~min}$ at $6000 \mathrm{rpm}$

14. Remove liquid and throw away. 
15. Send solids $101,104,107,110,113$, and 116 to Chuck Coleman for rad disc microwave digestion.

Table A2. Weights used in crystalline Fe-oxide fraction.

\begin{tabular}{llllll}
\hline ID\# & $\begin{array}{l}\text { Sediment } \\
\text { Description }\end{array}$ & Rep & $\begin{array}{l}\text { Centrifuge tare } \\
\text { wt. (g) }\end{array}$ & $\begin{array}{l}\text { Tare + sed. wet wt. at start of } \\
\text { cryst. Fe-oxide fraction (g) }\end{array}$ & $\begin{array}{l}\text { Tare + wet sed. + extract wt. for } \\
\text { cryst. Fe-oxide fraction (g) }\end{array}$ \\
\hline 501 & 101, BG5-0.4 & 1 & & & \\
502 & & 2 & & \\
503 & & 3 & & \\
504 & 102, A5-0 & 1 & & \\
505 & & 2 & & \\
506 & & 3 & & \\
507 & 103, B5-0.5 & 1 & & \\
508 & & 2 & & \\
509 & & 3 & & \\
510 & 104, C5-1 & 1 & & \\
511 & & 2 & & \\
512 & & 3 & & \\
513 & 105, D28-0 & 1 & & \\
514 & & 2 & & \\
515 & & 3 & & \\
516 & 105, B3-0.2 & 1 & & \\
517 & & 2 & & \\
518 & & 3 &
\end{tabular}

\section{Residual and Total Digestion}

1. Label and weigh aluminum weighing boats (1 for each tube).

2. Squirt di-water into the centrifuge tubes generated from Crystalline Fe-oxide Extraction to loosen and flush out the pellet into the aluminum boat.

3. Dry at $105^{\circ} \mathrm{C}$ until constant weight.

4. Add 0.2 to $0.3 \mathrm{~g}$ of dry residue to each Par Bomb teflon containers (1 per sample).

5. Add $1 \mathrm{~mL}$ Aqua regia $+10 \mathrm{~mL} 48 \%$ hydrofluoric acid to each vessel.

6. Place containers into Parr Bomb cases and the Parr Bombs cases into an over at $110^{\circ} \mathrm{C}$ for 3 hours.

7. Remove Parr Bombs from oven. Let cool to room temperature.

8. Pass through $0.45-\mu \mathrm{m}$ filter. Bring filtrate up to volume with di-water in a $25-\mathrm{ml}$ volumetric flask.

9. Send out for analysis.

\section{Chemical Analysis}

Chemical analyses were conducted by the Analytical Development Section (ADS), Measurement Technology Department, Savannah River Technology Center. Table A3 contains the types of analyses performed on each sample. 
Table A3. Samples to be submitted to ADS for chemical analyses.

\begin{tabular}{lllll}
\hline$\#$ & Sediment & Extract & Solid/Liquid & Analyses \\
\hline 1 & 101 & Water & Liquid & ICP-AES, ICP-MS, Hg, Se \\
2 & 102 & & Liquid & ICP-AES, ICP-MS, Hg, Se \\
3 & 103 & & Liquid & ICP-AES, ICP-MS, Hg, Se \\
4 & 104 & & Liquid & ICP-AES, ICP-MS, Hg, Se \\
5 & 105 & & Liquid & ICP-AES, ICP-MS, Hg, Se \\
6 & 106 & & Liquid & ICP-AES, ICP-MS, Hg, Se \\
7 & 101 & Acid & Liquid & ICP-AES, ICP-MS, Hg, Se \\
8 & 102 & & Liquid & ICP-AES, ICP-MS, Hg, Se \\
9 & 103 & & Liquid & ICP-AES, ICP-MS, Hg, Se \\
10 & 104 & & Liquid & ICP-AES, ICP-MS, Hg, Se \\
11 & 105 & & Liquid & ICP-AES, ICP-MS, Hg, Se \\
12 & 106 & & Liquid & ICP-AES, ICP-MS, Hg, Se \\
13 & 101 & Organic & Liquid & ICP-AES, ICP-MS, Hg, Se \\
14 & 102 & & Liquid & ICP-AES, ICP-MS, Hg, Se \\
15 & 103 & & Liquid & ICP-AES, ICP-MS, Hg, Se \\
16 & 104 & & Liquid & ICP-AES, ICP-MS, Hg, Se \\
17 & 105 & & Liquid & ICP-AES, ICP-MS, Hg, Se \\
18 & 106 & & Liquid & ICP-AES, ICP-MS, Hg, Se \\
19 & 101 & Amorphous Fe-oxide & Liquid & ICP-AES, ICP-MS, Hg, Se \\
20 & 102 & & Liquid & ICP-AES, ICP-MS, Hg, Se \\
21 & 103 & & Liquid & ICP-AES, ICP-MS, Hg, Se \\
22 & 104 & & Liquid & ICP-AES, ICP-MS, Hg, Se \\
23 & 105 & & Liquid & ICP-AES, ICP-MS, Hg, Se \\
24 & 106 & & Liquid & ICP-AES, ICP-MS, Hg, Se \\
25 & 101 & None & Solid & Organic Carbon \\
26 & 102 & & Solid & Organic Carbon \\
27 & 103 & & Solid & Organic Carbon \\
28 & 104 & & Solid & Organic Carbon \\
29 & 105 & & Solid & Organic Carbon \\
30 & 106 & & Solid & Organic Carbon \\
\hline
\end{tabular}


8. Appendix B: Detailed Sorption Kd Procedure 
The sorption Kd method is based on ASTM D 4319 [ASTM 1984]). Sample preservation followed EPA 245.1 Determination of Mercury in Water by Cold Vapor Atomic Absorption Spectrometry revision 3.0 5/94. Sample analyses were conducted by the General Engineering Laboratories (Charleston, SC), who followed EPA SW-846 Method 6010B by ICP and EPA SW846 Method 7470A by CVAA (Cold Vapor Atomic Absorption).

\section{Materials}

- $0.02 \mathrm{M} \mathrm{NaNO}_{3}(\mathrm{pH} 5.1)$

- Sediment TNXOD-BG5K, collected from an uncontaminated area of TNX near the Outfall Delta, depth of sample was 0.4 to $1.4 \mathrm{ft}$

- Uncontaminated TNX surface water $(<0.45-\mu \mathrm{m}$ filter $)$

- $1 \mathrm{mg} / \mathrm{L} \mathrm{Tl}$ (from $\mathrm{TlCl}$ ) in uncontaminated TNX surface water

- $10 \mathrm{mg} / \mathrm{L} \mathrm{Tl}$ (from $\mathrm{TlCl}$ ) in uncontaminated TNX surface water

- $0.2 \mathrm{ppm} \mathrm{Hg}$ (from mercury II nitrate monohydrate, Aldrich; also $1 \mathrm{e}-6 \mathrm{M} \mathrm{Hg}$ ) in uncontaminated TNX surface water. This was prepared using a $400 \mathrm{mg} / \mathrm{L} \mathrm{Hg}$ stock solution that was prepared by dissolving $34.16 \mathrm{mg} \mathrm{Hg}\left(\mathrm{NO}_{3}\right)_{2}-\mathrm{H}_{2} \mathrm{O}$ into $0.05-\mathrm{L} 0.1 \mathrm{M}$ $\mathrm{HNO}_{3}$. Then $0.125 \mathrm{~mL}$ of the $400 \mathrm{mg} / \mathrm{L} \mathrm{Hg}$ stock solution was brought up to $250 \mathrm{~mL}$ with TNX surface water $(<0.45-\mu \mathrm{m}, \mathrm{pH} 5.1)$.

- $2 \mathrm{ppm} \mathrm{Hg}$ (from mercury II nitrate monohydrate, Aldrich; also 1e-5 M Hg) in uncontaminated TNX surface water. This was prepared using a $400 \mathrm{mg} / \mathrm{L} \mathrm{Hg}$ stock solution that was prepared by dissolving $34.16 \mathrm{mg} \mathrm{Hg}\left(\mathrm{NO}_{3}\right)_{2}-\mathrm{H}_{2} \mathrm{O}$ into $0.05-\mathrm{L} 0.1 \mathrm{M}$ $\mathrm{HNO}_{3}$. Then $2.507 \mathrm{~mL}$ of the $400 \mathrm{mg} / \mathrm{L} \mathrm{Hg}$ stock solution was brought up to $250 \mathrm{~mL}$ with uncontaminated TNX surface water $(<0.45-\mu \mathrm{m}, \mathrm{pH} 5.1)$.

- $1 \mathrm{mg} / \mathrm{L} \mathrm{K}$ (from KCl) in $0.02 \mathrm{M} \mathrm{NaNO}_{3}(\mathrm{pH} 5.1)$

- $10 \mathrm{mg} / \mathrm{L} \mathrm{K}$ (from KCl) in $0.02 \mathrm{M} \mathrm{NaNO}_{3}$ (pH 5.1).

- $1.5 \mu \mathrm{Ci} / \mathrm{L}^{99} \mathrm{Tc}$ (from ${ }^{99} \mathrm{TcO}_{4}{ }^{-}$carrier-free source) in Uncontaminated TNX surface water

- $15-\mu \mathrm{Ci} / \mathrm{L}^{99} \mathrm{Tc}$ (from ${ }^{99} \mathrm{TcO}_{4}{ }^{-}$carrier-free source) in Uncontaminated $\mathrm{TNX}$ surface water

- $1 \mathrm{mg} / \mathrm{L} \mathrm{Ba}$ (from $\mathrm{BaCl}_{2}$ ) in Uncontaminated TNX surface water

- $10 \mathrm{mg} / \mathrm{L} \mathrm{Ba}$ (from $\mathrm{BaCl}_{2}$ in Uncontaminated TNX surface water

- Nitric Acid (1+1): Prepare this in non-rad hood. Add $500 \mathrm{~mL}$ concentrated Ultrex or UltraPure $\mathrm{HNO}_{3}$ to $400 \mathrm{~mL}$ of d.i. water and dilute to $1 \mathrm{~L}$.

\section{Methods}

1. Following the treatment description presented in Table B1, add 0.35-g sediment to tared Oak Ridge Tubes. Record "tare + sed dry wt."

2. Preequilibrate the sediments with 32 -hr washes with $0.02 \mathrm{M} \mathrm{NaNO}_{3}(\mathrm{pH} 5.1)$ for the $\mathrm{K}-\mathrm{Kd}$ tests and uncontaminated TNX surface water for all other Kd tests. At the end of each wash, centrifuge at $\sim 13000 \mathrm{~g}$ 's for $10 \mathrm{~min}$. Throw away the wash solutions being very careful not to lose any sediment. Error on the side of leaving liquid in the tube, rather than loosing solids. Record "tare + wet soil wt" after the third wash. 
3. Add $35 \mathrm{~mL}$ of the appropriate solution. Record "tare + wet soil + soln wt."

4. Put on shaker for 1 week.

5. Centrifuge and pass aqueous through $0.45-\mu \mathrm{m}$ filter.

6. Preserve aqueous sample by adding $3 \mathrm{~mL}$ Nitric Acid (1+1)/L sample [e.g., if you have $32 \mathrm{~mL}$ of filtrate sample, add $0.96 \mathrm{~mL}$ Nitric Acid (1+1)].

7. Save aqueous and analyze as follows

- K by AA flame

- Hg by AA-hydride generation

- $\mathrm{Ba}$ and Tc by ICP-ES

- Tc-99 by total nonvolatile beta (since the sample contained no other beta emitters, only Tc-99 contributed to the total nonvolatile beta activity.)

- Do complete cation (ICP-ms), anion (IC), total alkalinity (titration), and total organic and inorganic carbon (TIC and TOC) analyses of the uncontaminated surface water used in these experiments.

Table B1. Experimental Treatment Factorial

\begin{tabular}{|l|l|l|l|}
\hline ID \# & Element & $\begin{array}{l}\text { Target spike } \\
\text { Concentration }(\mathrm{ppm})\end{array}$ & Sediment Present \\
\hline $601-603$ & $\mathrm{Hg}$ & 0.2 & Present \\
\hline $604-606$ & & & Not Present \\
\hline $607-609$ & & 2 & Present \\
\hline $610-612$ & & 1 & Not Present \\
\hline $613-615$ & $\mathrm{~K}$ & & Present \\
\hline $616-618$ & & 10 & Not Present \\
\hline $619-621$ & & & Present \\
\hline $622-624$ & & 1 & Not Present \\
\hline $625-627$ & $\mathrm{Tl}$ & & Present \\
\hline $628-630$ & & 10 & Not Present \\
\hline $631-633$ & & & Present \\
\hline $634-636$ & & $1.5 \mu \mathrm{Ci} / \mathrm{L}$ & Not Present \\
\hline $637-639$ & $\mathrm{Tc}$ & & Present \\
\hline $640-642$ & & $15 \mu \mathrm{Ci} / \mathrm{L}$ & Not Present \\
\hline $643-645$ & & & Present \\
\hline $646-648$ & & 1 & Not Present \\
\hline $649-651$ & $\mathrm{Ba}$ & & Present \\
\hline $652-654$ & & 10 & Not Present \\
\hline $655-657$ & & & Present \\
\hline $658-660$ & & & Not Present \\
\hline
\end{tabular}


9. Appendix C: Supplemental Data 
Appendix C1. ICP-ES and AA Results (mg/L) from Desorption Kd Tests

\begin{tabular}{|c|c|c|c|c|c|c|c|c|c|c|c|c|c|c|c|}
\hline Sed & Extract & $\mathrm{Ag}$ & $\mathrm{Al}$ & $\mathrm{Ba}$ & $\mathrm{Be}$ & $\mathrm{Ce}$ & $\mathrm{Cr}$ & $\mathrm{Cu}$ & $\mathrm{Fe}$ & $\mathrm{Mn}$ & $\mathrm{Ni}$ & $\mathrm{Pb}$ & $\mathrm{Sr}$ & $\mathrm{Tl}$ & $\mathrm{Se}$ \\
\hline 101 & water & 0.04 & 0.418 & 0.173 & 0.001 & 0.315 & 0.009 & 0.006 & 0.122 & 3.337 & 0.021 & 0.029 & 0.075 & 0.328 & 0.00625 \\
\hline 102 & water & 0.004 & 3.304 & 0.015 & 0.001 & 0.315 & 0.036 & 0.066 & 3.484 & 0.038 & 0.03 & 0.029 & 0.015 & 0.134 & 0.0067 \\
\hline 103 & water & 0.004 & 4.909 & 0.019 & 0.001 & 0.315 & 0.113 & 0.069 & 6.265 & 0.016 & 0.021 & 0.029 & 0.025 & 0.134 & 0.007 \\
\hline 104 & water & 0.04 & 17.432 & 0.066 & 0.01 & 3.15 & 0.946 & 0.177 & 20.736 & 0.07 & 0.13 & 0.29 & 0.047 & 1.341 & 0.00725 \\
\hline 105 & water & 0.004 & 7.121 & 0.038 & 0.001 & 0.315 & 0.021 & 0.029 & 4.639 & 0.037 & 0.013 & 0.029 & 0.04 & 0.207 & 0.0109 \\
\hline 106 & water & 0.004 & 11.891 & 0.035 & 0.001 & 0.315 & 0.041 & 0.029 & 3.32 & 0.081 & 0.013 & 0.029 & 0.041 & 0.19 & 0.0101 \\
\hline 101 & acid & 0 & 16.42 & 0.424 & 0 & 0 & 0.167 & 0 & 0.436 & 2.164 & 0 & 0 & 2.028 & 105.96 & 0.00145 \\
\hline 102 & acid & 0 & 42.314 & 2.906 & 0.016 & 0 & 0.314 & 0.281 & 19.024 & 3.047 & 0.277 & 0 & 2.265 & 99.933 & 0.0024 \\
\hline 103 & acid & 0 & 18.551 & 0.497 & 0 & 0 & 0.338 & 0.179 & 21.781 & 0.853 & 0.279 & 0 & 2.132 & 95.629 & 0.0032 \\
\hline 104 & acid & 0 & 15.819 & 0.583 & 0 & 0 & 0.248 & 0.134 & 16.604 & 0.701 & 0.134 & 0 & 2.066 & 93.907 & 0.004 \\
\hline 105 & acid & 0 & 41.265 & 1.106 & 0 & 0 & 0.258 & 0.114 & 4.879 & 0.241 & 0 & 0 & 2.158 & 95.629 & 0.00475 \\
\hline 106 & acid & 0 & 19.737 & 0.481 & 0 & 0 & 0.275 & 0 & 2.425 & 0.457 & 0 & 0 & 2.144 & 105.1 & 0.0053 \\
\hline 101 & organic & 0.073 & 24.668 & 0.125 & 0 & 0 & 0.275 & 0 & 15.241 & 0.202 & 0 & 0 & 0.528 & 0 & 0.02442 \\
\hline 102 & organic & 0.047 & 154.32 & 0.334 & 0 & 0 & 1.104 & 0.384 & 220.58 & 0.619 & 0 & 0 & 0.671 & 0 & 0.0429 \\
\hline 103 & organic & 0.086 & 102.33 & 0.259 . & 0 & 0 & 1.559 & 0.194 & 180.35 & 0.134 & 0 & 0.547 & 0.721 & 0 & 0.05016 \\
\hline 104 & organic & 0.1 & 135.15 & 0.182 & 0 & 0 & 1.255 & 0.277 & 110.37 & 0.119 & 0.135 & 0.538 & 0.728 & 0 & 0.05346 \\
\hline 105 & organic & 0.042 & 111.57 & 0.197 & $\mathbf{0}$ & 0 & 0.831 & 0.174 & 84.598 & 0.08 & 0 & 0.293 & 0.676 & 0 & 0.06402 \\
\hline 106 & organic & 0 & 57.256 & 0.108 & 0 & 0 & 0.813 & 0.079 & 38.111 & 0.224 & 0 & 0 & 0.377 & 0 & 0.06798 \\
\hline 101 & AmFeOx & 0 & 4.138 & 0 & 0 & 0 & 0.247 & 0 & 2.43 & 0.274 & 0 & 0 & 0 & 0 & 0.00 .6 \\
\hline 102 & AmFeOx & 0 & 21.6 & 0 & 0 & 0 & 0.391 & 0 & 65.908 & 0.499 & 0 & 0 & 0 & 9.356 & 0.00456 \\
\hline 103 & AmFeOx & 0 & 9.335 & 0 & 0 & 0 & 0.367 & 0 & 77.323 & 0 & 0 & 0 & 0 & 0 & 0.0048 \\
\hline 104 & AmFeOx & 0.211 & 9.165 & 0 & 0 & 0 & 0.367 & 0 & 13.207 & 0 & 0 & 0 & 0 & 8.055 & 0.00504 \\
\hline 105 & AmFeOx & 0 & 15.8 & 0 & 0 & 0 & 0.256 & 0 & 34.23 & 0 & 0 & 0 & 0 & 8.922 & 0.0054 \\
\hline 106 & $\mathrm{AmFeOx}$ & 0.236 & 8.824 & 0 & 0 & 0 & 0.364 & 0 & 9.778 & 0.146 & 0 & 0 & 0 & 7.621 & 0.00582 \\
\hline
\end{tabular}

Comments:

- To facilitate spreadsheet calculations of Kd values, zero's were entered in "below-detection limit" values.

- For the Acid, Organic, and Amorphous Fe-oxide extracts, $0 \mathrm{mg} / \mathrm{L}$ were entered into spreadsheet so that these values could be included in summation to generate the $\mathrm{C}_{\text {solid }}$ values used in the $\mathrm{Kd}_{\max }$ calculations.

- Tl values determined by ICP-ES are suspect because they are unrealistically high and essentially no Tl was detected by ICP-MS. Based on conversations with the spectroscopist, the $\mathrm{Tl}$ is likely the result of spectral interferences. 
Appendix C2. ICP-MS Analytical Results $(\mu \mathrm{g} / \mathrm{L})$ for Desorption Kd Tests.

\begin{tabular}{|c|c|c|c|c|c|c|c|c|c|c|c|c|c|c|}
\hline ID & Extract & $\mathrm{Co}$ & $\mathrm{Ni}$ & $\mathrm{Cu}$ & $\mathrm{Zn}$ & As & $\mathrm{Sr}$ & $\mathrm{Ag}$ & $\mathrm{Cd}$ & $\mathrm{Ce}$ & $\mathrm{Tl}$ & $\mathrm{Pb}$ & $\mathrm{Th}$ & $\mathrm{U}$ \\
\hline 101 & water & 0.06 & 0.15 & 0.18 & 0.82 & 0.06 & 76.75 & 159.67 & 0.01 & 0.01 & 0.00 & 0.21 & 0 & 0 \\
\hline 102 & water & 0.06 & 18268.68 & 76.10 & 0.82 & 0.06 & 15.66 & 75.63 & 29.96 & 21.54 & 0.00 & 0.21 & 0 & 120.44 \\
\hline 103 & water & 0.06 & 0.15 & 82.14 & 0.82 & 6.50 & 26.81 & 59.60 & 0.01 & 7.00 & 0.00 & 0.21 & 390.74 & 253.30 \\
\hline 104 & water & 0.06 & 0.15 & 196.00 & 0.82 & 35.85 & 48.36 & 31.15 & 0.01 & 58.22 & 0.00 & 0.21 & 1779.43 & 3054.05 \\
\hline 105 & water & 0.06 & 0.15 & 32.45 & 0.82 & 0.06 & 42.47 & 28.34 & 0.01 & 7.23 & 0.00 & 0.21 & 26.01 & 39.74 \\
\hline 106 & water & 0.06 & 0.15 & 27.17 & 0.82 & 0.06 & 42.99 & 15.80 & 0.01 & 6.45 & 0.00 & 0.21 & & 126.83 \\
\hline 101 & acid & 22.19 & 95.68 & 40.94 & 0 & 0 & 2288.01 & 144.29 & 0 & 209.51 & 0 & 0 & 0 & 0 \\
\hline 102 & acid & 97.59 & 445.29 & 32.03 & 0 & 0 & 2435.88 & 0 & 11.79 & 1012.63 & 0 & 53.42 & 43.59 & 1605.89 \\
\hline 103 & acid & 50.27 & 466.05 & 229.42 & 0 & 0 & 2319.13 & 0 & 0 & 169.53 & 0 & 17.48 & 365.18 & 4941.60 \\
\hline 104 & acid & 32.90 & 260.40 & 171.00 & 0 & 11.89 & 2279.87 & 0 & & 236.17 & 0 & 64.36 & 23.36 & 5422.42 \\
\hline 105 & acid & 33.46 & 261.22 & 152.43 & 0 & 0 & 2359.11 & 0 & 5.04 & 614.49 & 0 & 111.43 & 12.01 & 2517.09 \\
\hline 106 & acid & 0 & 164.28 & 80.80 & 0 & 0 & 2302.32 & 0 & 0 & 193.69 & 0 & 31.97 & 4.97 & 4407.01 \\
\hline 101 & organic & 7.58 & 44.30 & 114.50 & 0 & 0 & 37.99 & 2491.66 & 0 & 94.00 & 0 & 0 & 45.12 & 11.28 \\
\hline 102 & organic & 28.06 & 211.83 & 447.63 & 0 & 61.48 & 100.65 & 1298.51 & 28.33 & 642.27 & 0 & 165.14 & 6617.87 & 3310.08 \\
\hline 103 & organic & 12.56 & 188.04 & 236.70 & 950.59 & 69.77 & 127.06 & 800.53 & 8.15 & 170.98 & 0 & 124.66 & 17575.92 & 4749.28 \\
\hline 104 & organic & 14.48 & 136.13 & 318.05 & 0 & 55.74 & 84.26 & 360.69 & 0 & 280.38 & 0 & 190.23 & 6397.70 & 11843.13 \\
\hline 105 & organic & 12.46 & 151.53 & 248.88 & 0 & 2590 & 72.56 & 0 & 0 & 332.41 & 0 & 145.07 & 1681.25 & 5161.29 \\
\hline 106 & organic & 10.62 & 116.40 & 167.66 & 0 & 0 & 57.49 & 0 & 5.25 & 90.57 & 0 & 46.81 & 1461.98 & 3876.18 \\
\hline 101 & $\mathrm{AmFeOx}$ & 0 & 0.26 & 0.69 & & 34.78 & 8.38 & 970.11 & 0 & 0.90 & 14.47 & 0 & 27.97 & 0 \\
\hline 102 & AmFeOx & 9.28 & 0 & 129.06 & 1752.22 & 43.51 & 8.19 & 674.18 & 0 & 2.30 & 0 & 64.89 & 766.73 & 226.01 \\
\hline 103 & AmFeOx & 0 & 0 & 60.35 & 0 & 47.27 & 6.87 & 529.65 & 0 & 0.81 & 0 & 0 & 3831.43 & 769.41 \\
\hline 104 & $\mathrm{AmFeOx}$ & 0 & 0 & 45.06 & 0 & 0 & 6.08 & 386.18 & 0 & 1.05 & 0 & 0 & 490.74 & 584.56 \\
\hline 105 & AmFeOx & 0 & 0 & 49.01 & 0 & 29.47 & 7.07 & 342.52 & 0 & 0.75 & 0 & 0 & 122.45 & 444.86 \\
\hline 106 & AmFeOx & 0 & 0 & 0 & 0 & 0 & 8.04 & 155.96 & 0 & 0 & 0 & 0 & 110.92 & 311.26 \\
\hline
\end{tabular}

Comments:

- To facilitate spreadsheet calculations of Kd values, zeros were entered in "below-detection limit" values.

- For Acid, Organic, and Amorphous Fe-oxide values that were below detection limit, $0 \mu \mathrm{g} / \mathrm{L}$ were entered to permit spreadsheet calculations of $\mathrm{Kd} \mathrm{d}_{\text {max }}$ values. 
Appendix C3. Elemental Concentrations of Whole, <2-um, and 0.5-um Fractions of Sediment and Solid and Liquid Amounts Used in Total Dissolution Procedure

\begin{tabular}{|c|c|c|c|c|c|c|c|c|c|c|c|c|c|}
\hline & & $\begin{array}{c}\mathrm{Ag} \\
/ \mathrm{mL})^{-}\end{array}$ & $\begin{array}{c}\mathrm{Cd} \\
/ \mathrm{mL})\end{array}$ & $\begin{array}{r}\mathrm{Ce} \\
(\mathrm{mL})\end{array}$ & $\begin{array}{c}\mathrm{Hg} \\
/ \mathrm{mL})\end{array}$ & $\begin{array}{c}\mathrm{Pb} \\
/ \mathrm{mL})\end{array}$ & $\mathrm{g} / \mathrm{mL})^{\mathrm{Sr}}$ & $(\mathrm{mL})$ & $\begin{array}{l}\text { Th } 232 \\
\mathrm{gg} / \mathrm{mL})\end{array}$ & $\begin{array}{r}\mathrm{U}-235 \\
(\mathrm{ng} / \mathrm{mL})\end{array}$ & \multicolumn{2}{|c|}{ U-238 Solids } & $\begin{array}{l}\text { Liquid } \\
\text { (mL) }\end{array}$ \\
\hline \multirow[t]{3}{*}{101} & Whole & 0.009 & 0.003 & 2377 & 0.019 & 502 & 210 & 14.4 & 332 & 0.003 & 70 & 3.0634 & 25.00 \\
\hline & $<2$-um & 209 & 0.003 & 5107 & 10 & 1241 & 412 & 62.6 & 506 & 0.003 & 146 & 1.9991 & 25.00 \\
\hline & $<0.5$-um & 42 & 0.003 & 516 & 6 & 220 & 31 & 15.6 & 286 & 0.003 & 23 & 0.2893 & 25.00 \\
\hline \multirow[t]{3}{*}{102} & Whole & 170 & 32 & 5046 & 335 & 1659 & 744 & 7.1 & 18938 & 113 & 17681 & 2.3554 & 25.00 \\
\hline & $<2$-um & 0.009 & 0.003 & 2729 & 0.019 & 0.013 & 0.007 & 0.006 & 11223 & 46 & 7355 & 1.2499 & 25.00 \\
\hline & $<0.5$-um & 54 & 0.003 & 807 & 13 & 399 & 67 & 49.6 & 4004 & 0.003 & 2467 & 0.4830 & 25.00 \\
\hline \multirow[t]{3}{*}{103} & Whole & 0.009 & 0.003 & 1278 & 0.019 & 0.013 & 0.007 & 8.9 & 5608 & 241 & 32317 & 2.8338 & 25.00 \\
\hline & $<2$-um & 172 & 8 & 1434 & 341 & 1453 & 627 & 85.1 & 108606 & 181 & 31990 & 1.8690 & 25.00 \\
\hline & $<0.5$-um & 41 & 3 & 669 & 124 & 761 & 25.005 & 60.3 & 52264 & 85 & 15499 & 1.1011 & 25.00 \\
\hline \multirow[t]{3}{*}{104} & Whole & 74 & 1 & 1054 & 585 & 1066 & 423 & 8.8 & 70815 & 184 & 33544 & 2.5478 & 25.00 \\
\hline & $<2$-um & 111 & 0.003 & 1766 & 314 & 1600 & 239 & 65.4 & 72078 & 385 & 54314 & 2.1205 & 25.00 \\
\hline & $<0.5$-um & 37 & 0.003 & 804 & 138 & 832 & 112 & 51.2 & 40405 & 174 & 25346 & 1.2585 & 25.00 \\
\hline \multirow[t]{3}{*}{105} & Whole & 27 & 5 & 1595 & 582 & 1438 & 166 & 0.0 & 41359 & 427 & 59300 & 2.6508 & 25.00 \\
\hline & $<2$-um & 102 & 8 & 3219 & 34 & 2665 & 230 & 56.6 & 5708 & 136 & 23391 & 2.2362 & 25.00 \\
\hline & $<0.5$-um & 35 & 0.003 & 1385 & 15 & 1396 & 97 & 44.1 & 2966 & 61 & 10961 & 0.9796 & 25.00 \\
\hline \multirow[t]{3}{*}{106} & Whole & 36 & 6 & 3479 & 29 & 2636 & 329 & 14.1 & 3089 & 168 & 30465 & 2.6472 & 25.00 \\
\hline & $<2$-um ${ }^{\circ}$ & 0.009 & 0.003 & 2136 & 0.019 & 1865 & 0.007 & 0.006 & 14280 & 416 & 55999 & 2.1660 & 25.00 \\
\hline & $<0.5$-um & 0.009 & 0.003 & 897 & 0.019 & 858 & 0.007 & 0.006 & 6354 & 189 & 25403 & 1.0029 & 25.00 \\
\hline
\end{tabular}

Comments:

- Bold values for water extracts are detection limits. 
Table C4. Elemental Composition of Totally Digested (Aqua Regia) Samples of Intact Sediments

\begin{tabular}{cccccccccc} 
Sediment & $\mathrm{Ag}$ & $\mathrm{Al}$ & $\mathrm{As}$ & $\mathrm{Ba}$ & $\mathrm{Be}$ & $\mathrm{Ce}$ & $\mathrm{Cr}$ & $\mathrm{Cu}$ & $\mathrm{Fe}$ \\
\hline 101 & 0.49 & 1915.24 & 1.52 & 21.97 & 0.47 & 4.85 & 2.82 & 2.19 & 2634.83 \\
102 & 2.18 & 6251.78 & 35.28 & 78.72 & 0.80 & 62.82 & 44.60 & 28.39 & 7533.14 \\
103 & 0.53 & 2828.15 & 4.36 & 16.37 & 0.20 & 25.48 & 30.65 & 5.14 & 1797.92 \\
104 & 2.03 & 2338.11 & 2.47 & 17.33 & 0.23 & 37.35 & 66.26 & 12.56 & 5490.17 \\
105 & 1.30 & 3371.36 & 2.28 & 15.82 & 0.15 & 38.66 & 78.16 & 13.69 & 3885.48 \\
106 & 0.57 & 4847.01 & 0.42 & 28.62 & 0.52 & 10.67 & 25.91 & 9.77 & 3793.74 \\
\hline & & & & & & & & & \\
\hline Sediment & $\mathrm{Hg}$ & $\mathrm{Mn}$ & $\mathrm{Ni}$ & $\mathrm{Pb}$ & $\mathrm{Sr}$ & $\mathrm{Tl}$ & $\mathrm{Th}-232$ & $\mathrm{U}-235$ & $\mathrm{U}-238$ \\
\hline 101 & 0.03 & 84.28 & 1.45 & 0.00 & 1.46 & 10.94 & 2.32 & 0.00 & 3.78 \\
102 & 6.82 & 114.37 & 15.97 & 49.83 & 7.16 & 16.16 & 231.08 & 1.07 & 171.00 \\
103 & 0.52 & 25.11 & 4.26 & 44.27 & 3.20 & 11.83 & 871.16 & 1.93 & 415.57 \\
104 & 9.45 & 20.84 & 8.34 & 63.71 & 3.61 & 13.16 & 241.97 & 4.12 & 613.63 \\
105 & 9.20 & 22.18 & 5.41 & 58.95 & 1.31 & 14.36 & 61.29 & 1.52 & 298.06 \\
106 & 0.64 & 13.52 & 7.45 & 15.96 & 2.59 & 17.42 & 51.18 & 1.94 & 303.38 \\
\hline
\end{tabular}


Table C5. Correlation Coefficients Between COC Kd Values and Soil Properties (Excluded "Greater Than Kd Values" From These Calculations.

\begin{tabular}{|c|c|c|c|c|c|c|c|c|c|c|c|c|}
\hline & $<2-m m$ & Sand & Silt & Clay & $\overline{p H}$ & Organic C & $C E C$ & $A E C$ & Fe-oxides & & & \\
\hline$\overline{\text { Sand }}$ & -0.67 & 1.00 & & & & & & & & & & \\
\hline Silt & 0.12 & -0.70 & 1.00 & & & & & & & & & \\
\hline Clay & -0.23 & -0.38 & 0.21 & 1.00 & & & & & & & & \\
\hline $\mathrm{pH}$ & -0.53 & 0.19 & 0.24 & 0.15 & 1.00 & & & & & & & \\
\hline Organic $\mathrm{C}$ & 0.54 & -0.35 & -0.11 & 0.06 & $-0.97^{(a)}$ & 1.00 & & & & & & \\
\hline CEC & 0.46 & -0.86 & 0.92 & 0.11 & 0.14 & -0.02 & 1.00 & & & & & \\
\hline AEC & 0.21 & -0.07 & 0.46 & -0.76 & 0.03 & -0.13 & 0.47 & 1.00 & & & & \\
\hline Fe-oxides & 0.40 & -0.94 & 0.87 & 0.45 & -0.05 & 0.24 & 0.89 & 0.13 & 1.00 & & & \\
\hline Al-Kd & 0.22 & 0.44 & -0.71 & -0.53 & -0.71 & 0.56 & -0.62 & 0.01 & -0.57 & & & \\
\hline $\mathrm{Ba}-\mathrm{Kd}$ & 0.99 & -0.64 & 0.13 & -0.28 & -0.50 & 0.50 & 0.48 & 0.28 & 0.37 & & & \\
\hline Be-Kd & 0.86 & -1.00 & 0.89 & 0.91 & 0.86 & 0.94 & 0.95 & -0.49 & 1.00 & & & \\
\hline Ce-Kd & 0.15 & -0.04 & -0.22 & 0.00 & -0.61 & 0.56 & -0.25 & -0.03 & -0.11 & & & \\
\hline $\mathrm{Cr}-\mathrm{Kd}$ & 0.02 & 0.53 & -0.67 & -0.45 & -0.59 & 0.43 & -0.64 & 0.02 & -0.65 & & & \\
\hline $\mathrm{Cu}-\mathrm{Kd}$ & 0.57 & -0.48 & -0.13 & -0.13 & -0.89 & 0.83 & 0.08 & 0.07 & 0.20 & & & \\
\hline Fe-Kd & 0.21 & 0.45 & -0.76 & -0.47 & -0.68 & 0.54 & -0.67 & -0.09 & -0.60 & & & \\
\hline Mn-Kd & 0.94 & -0.75 & 0.11 & 0.08 & -0.44 & 0.51 & 0.45 & -0.09 & 0.49 & & & \\
\hline Se-Kd & 0.04 & -0.66 & 0.65 & 0.67 & 0.55 & -0.36 & 0.67 & -0.21 & 0.71 & & & \\
\hline Sr-Kd & 0.95 & -0.79 & 0.18 & 0.06 & -0.43 & 0.50 & 0.52 & -0.01 & 0.53 & & & \\
\hline Th-Kd & 0.52 & 0.08 & -0.82 & 0.51 & -1.00 & 0.98 & -0.90 & -0.57 & -0.93 & & & \\
\hline $\mathrm{U} 238-\mathrm{Kd}$ & -0.24 & 0.28 & -0.12 & 0.08 & -0.30 & 0.27 & -0.37 & -0.03 & -0.24 & & & \\
\hline & $A l-K d$ & $B a-K d$ & $B e-K d$ & $\mathrm{Ce}-\mathrm{Kd}$ & $C r-K d$ & $C u-K d$ & $F e-K d$ & $M n-K d$ & $S e-K d$ & $S r-K d$ & $T h-K d$ & $U-238$ \\
\hline Ba-Kd & 0.19 & 1.00 & & & & & & & & & & \\
\hline $\mathrm{Be}-\mathrm{Kd}$ & -0.98 & 1.00 & 1.00 & & & & & & & & & \\
\hline $\mathrm{Ce}-\mathrm{Kd}$ & 0.36 & 0.22 & -1.00 & 1.00 & & & & & & & & \\
\hline Cr-Kd & 0.71 & 0.07 & -0.76 & 0.94 & 1.00 & & & & & & & \\
\hline $\mathrm{Cu}-\mathrm{Kd}$ & 0.74 & 0.61 & -1.00 & 0.88 & 0.83 & 1.00 & & & & & & \\
\hline Fe-Kd & 0.99 & 0.17 & -0.96 & 0.30 & 0.69 & 0.67 & 1.00 & & & & & \\
\hline Mn-Kd & 0.10 & 0.90 & 0.72 & 0.02 & -0.17 & 0.45 & 0.12 & 1.00 & & & & \\
\hline Se-Kd & -0.90 & 0.03 & 0.97 & -0.74 & -0.85 & -0.80 & -0.87 & 0.26 & 1.00 & & & \\
\hline Sr-Kd & 0.02 & 0.94 & 0.92 & 0.17 & -0.12 & 0.58 & 0.03 & 0.98 & 0.28 & 1.00 & & \\
\hline Th-Kd & 0.94 & 0.93 & -1.00 & 0.87 & 0.85 & 0.91 & 0.78 & 0.29 & -0.45 & 0.56 & 1.00 & \\
\hline U238-Kd & -0.03 & -0.16 & -1.00 & 0.92 & 0.83 & 0.64 & -0.09 & -0.37 & -0.58 & -0.23 & 0.78 & 1.00 \\
\hline
\end{tabular}

(a) In Bold Font: Correlation coefficients greater than $0.95,0.88,0.81$ and 0.75 , with 2, 3, 4, and 5 degrees of freedoms, respectively, are significant at $P<$ 0.05 level ( $5 \%$ probability level). 